Article

\title{
Nicotine Changes Airway Epithelial Phenotype and May Increase the SARS-COV-2 Infection Severity
}

\author{
Leonardo Lupacchini ${ }^{1}$, Fabrizio Maggi ${ }^{2} \mathbb{(}$, Carlo Tomino ${ }^{3, *}$, Chiara De Dominicis ${ }^{1}$, Cristiana Mollinari ${ }^{4,5}$, \\ Massimo Fini ${ }^{3}$, Stefano Bonassi ${ }^{6,7} \mathbb{D}$, Daniela Merlo ${ }^{5}$ and Patrizia Russo ${ }^{6,7, *}$
}

check for

updates

Citation: Lupacchini, L.; Maggi, F.; Tomino, C.; De Dominicis, C.; Mollinari, C.; Fini, M.; Bonassi, S.; Merlo, D.; Russo, P. Nicotine Changes Airway Epithelial Phenotype and May Increase the SARS-COV-2 Infection Severity. Molecules 2021, 26, 101. https://doi.org/10.3390/ molecules26010101

Academic Editor: Thomas J. Schmidt Received: 4 November 2020 Accepted: 24 December 2020 Published: 28 December 2020

Publisher's Note: MDPI stays neutral with regard to jurisdictional clai$\mathrm{ms}$ in published maps and institutional affiliations.

Copyright: $@ 2020$ by the authors. Licensee MDPI, Basel, Switzerland. This article is an open access article distributed under the terms and conditions of the Creative Commons Attribution (CC BY) license (https:// creativecommons.org/licenses/by/ $4.0 /)$.
1 Molecular and Cellular Neurobiology, IRCSS San Raffaele Pisana, Via di Val Cannuta 247, I-00166 Rome, Italy; leonardo.lupacchini@sanraffaele.it (L.L.); chiaradedominicisjob@gmail.com (C.D.D.)

2 Department of Medicine and Surgery, University of Insubria, viale Luigi Borri 57, I-21100 Varese, Italy; fabrizio.maggi63@gmail.com

3 Scientific Direction, IRCSS San Raffaele Pisana, Via di Val Cannuta 247, I-00166 Rome, Italy; massimo.fini@sanraffaele.it

4 Institute of Translational Pharmacology, National Research Council, Via Fosso del Cavaliere 100, 00133 Rome, Italy; cristiana.mollinari@ift.cnr.it

5 Department of Neuroscience, Istituto Superiore di Sanità, Viale Regina Elena 299, I-00161 Rome, Italy; daniela.merlo@iss.it

6 Clinical and Molecular Epidemiology, IRCSS San Raffaele Pisana, Via di Val Cannuta 247, I-00166 Rome, Italy; stefano.bonassi@uniroma5.it

7 Department of Human Sciences and Quality of Life Promotion, San Raffaele University, Via di Val Cannuta 247, I-00166 Rome, Italy

* Correspondence: carlo.tomino@sanraffaele.it (C.T.); patrizia.russo@uniroma5.it or patrizia_russo@hotmail.it (P.R.)

Abstract: (1) Background: Nicotine is implicated in the SARS-COV-2 infection through activation of the $\alpha 7-\mathrm{nAChR}$ and over-expression of ACE2. Our objective was to clarify the role of nicotine in SARS-CoV-2 infection exploring its molecular and cellular activity. (2) Methods: HBEpC or si-mRNA- $\alpha 7-H B E p C$ were treated for $1 \mathrm{~h}, 48 \mathrm{~h}$ or continuously with $10^{-7} \mathrm{M}$ nicotine, a concentration mimicking human exposure to a cigarette. Cell viability and proliferation were evaluated by trypan blue dye exclusion and cell counting, migration by cell migration assay, senescence by SA- $\beta$-Gal activity, and anchorage-independent growth by cloning in soft agar. Expression of Ki67, p53/phospho-p53, VEGF, EGFR/pEGFR, phospho-p38, intracellular $\mathrm{Ca}^{2+}$, ATP and EMT were evaluated by ELISA and/or Western blotting. (3) Results: nicotine induced through $\alpha 7-$ nAChR (i) increase in cell viability, (ii) cell proliferation, (iii) Ki67 over-expression, (iv) phosphop38 up-regulation, (v) EGFR/pEGFR over-expression, (vi) increase in basal $\mathrm{Ca}^{2+}$ concentration, (vii) reduction of ATP production, (viii) decreased level of p53/phospho-p53, (ix) delayed senescence, (x) VEGF increase, (xi) EMT and consequent (xii) enhanced migration, and (xiii) ability to grow independently of the substrate. (4) Conclusions: Based on our results and on evidence showing that nicotine potentiates viral infection, it is likely that nicotine is involved in SARS-CoV-2 infection and severity.

Keywords: cell proliferation; EMT; mitochondrial dysfunction; nAChR; nicotine; SARS-CoV-2

\section{Introduction}

Nicotine (Table 1) [1-9] is the addictive compound of tobacco and exerts its effect after binding to $\mathrm{AAChR}$ [10-12]. ACh, mAChR, VAChT, AChE, BuChE, and ChAT are all components of the CS. ACh is the natural ligand of both $\mathrm{nAChR}$ and $\mathrm{mAChR}$.

$\mathrm{nAChR}$ pertain to the super-family of Cys-loop ion channel receptors consisting of nine $\alpha$ (from $\alpha 2$ to $\alpha 10$ ) and three $\beta$ subunits (from $\beta 2$ to $\beta 4$ ) activated by the physiological ligand $\mathrm{ACh}$ or by the non-physiologic ligand nicotine. At least two $\alpha$ subunits are needed in each $\mathrm{nAChR}$ pentamer to bind the ligand, since the binding site is localized inside a 
groove between the extracellular domains formed by an $\alpha$ subunit and an adjacent subunit. Nicotine binds with high affinity to the $\alpha_{4} \beta_{2}$-nAChR with a $K_{i}=1 \mathrm{nM}$ inducing a desensitized state that in turn reduces functional activity of the $\alpha_{4} \beta_{2}$-nAChR [13], and with low affinity binding to the $\alpha 7$ receptor with $\mathrm{K}_{\mathrm{i}}=1600 \mathrm{nM}$ [14]. This observation is important because means that $\alpha_{4} \beta_{2}$-nAChR are desensitized by nicotine and thus are not able to function. A recent work, using a comprehensive "methyl scan" approach, shows that the orthosteric (i.e., site where the endogenous ligand binds and produces its effects) binding sites for ACh and nicotine in the $\alpha_{4} \beta_{2}$-nAChR and the $\alpha 7-n A C h R$ interact differently with the pyrrolidinium ring of nicotine, and suggests possible reasons for the higher affinity of nicotine for $\alpha_{4} \beta_{2}$-nAChR [15]. The $\alpha_{4} \beta_{2}$-nAChR are prevalently localized on the brain and mediate many behaviors related to nicotine addiction and are the primary targets for currently approved smoking cessation agents $[12,16]$. Lung epithelial cells (unaffected and cancer cells) express different $\mathrm{nAChR}$ [17]. It has been reported that, although there is a significant reduction in $\alpha 4-n A C h R$ expression in lung cancer [18], there is so far no further evaluation of its role in normal bronchial epithelium. It has been hypothesized that $\alpha 7$ and $\alpha_{4} \beta_{2} n A C h R$ activation may be associated with transactivation via cAMP stimulation of EGFR signaling pathways inducing cell growth and proliferation, thus may contribute to carcinogenesis [19]. The role of the $\alpha 7$ receptor is the best characterized on the lung [12].

Table 1. Nicotine: Chemical, physical, biological characteristics and historical data.

\begin{tabular}{cc}
\hline Common Name & Nicotine \\
\hline IUPAC Name & 3-(1-methyl-2-pyrrolidinyl)pyridine \\
\hline Chemical Specification & $\begin{array}{c}\text { Bicyclic molecule characterized by a pyridine cycle and a pyrrolidine cycle existing in } \\
\text { natures only in the S shape (i.e., levogyre) [1] }\end{array}$ \\
\hline Chemical Characteristics & $\begin{array}{c}\text { Chemical formula: } \mathrm{C}_{10} \mathrm{H}_{14} \mathrm{~N}_{2} \\
\text { Molecular Weight: } 162.234 .\end{array}$
\end{tabular}

Light yellow liquid that turns dark-brown after exposure to light/air with fishy odor

Physical Characteristics when warm.

Boiling point: $274.58^{\circ} \mathrm{C}$ at 760 Tor [2]

Synthesized as SM by plants

Production, Use and Natural Resistance
Familia: Solanaceae, Genus: Nicotiana, Species: Nicotiana tabacum

1492 Cristoforo Colombo discovery of the plant Nicotiana.

Nicotine owes is name to Jean Nicot (1530-1604) who introduced the use of tobacco to the French court (Caterina de Medici) in the sixteenth century, thus helping the spread of tobacco into all Europe [3]

1828 the German chemists Wilhelm Heinrich Posselt and Karl Ludwig Reimann were the first to isolate nicotine from tobacco.

1843 Louis Melsens described the chemical formula.

1893 Adolf Pinner and Richard Wolffenstein described the structure.

1904 Amé Pictet and Arnold Rotschy, synthesized nicotine [3]

Plants produce SM, metabolites not essential for plant reproduction, as direct defenses against pathogens (i.e., insects) and herbivores. Among SM, nicotine is one of the best-studied drug representing one of the first insecticides utilized to control pests in agriculture [4].

Although nicotine is very toxic, some insects develop resistance, indeed the tobacco hornworm Manduca sexta may survive to nicotine concentrations that are considered toxic for non-adapted herbivores [4].

Although the precise mechanisms for Manduca sexta's nicotine resistance are not completely understood, an efficient excretion and metabolism seem to be involved.

Manduca sexta uses nicotine to protect herself by the attack of its native major nocturnal predator wolf spider Camptocosa parallela [5]

Concentration in Tobacco leaves
The percentage of nicotine on dry weight of tobacco is between 0.3 to $8.3 \%$ depending on plant variety, as for Nicotiana gossei and Nicotiana velutina, respectively, and $6.7 \%$ in Virginia variety, and cultivation [6]

In animals the lethal dose may be from $3 \mathrm{mg} / \mathrm{kg}$ in mice to $50 \mathrm{mg} / \mathrm{kg}$ in rats. There is no consensus on the human lethal dose of nicotine and $60 \mathrm{mg}$ of nicotine 
Table 1. Cont.

\begin{tabular}{cr}
\hline Common Name & Nicotine \\
\hline Metabolism & $\begin{array}{r}\text { Nicotine is metabolized in the liver, principally to cotinine that in turn is metabolized } \\
\text { to trans-3'-hydroxycotinine excreted via renal [8] }\end{array}$ \\
$\begin{array}{c}\text { The amount of nicotine in one tobacco cigarette is approximately } 1-2 \%=1-2 \mathrm{~g} / 100 . \\
\text { Considering the human body weight average equal to } 68 \mathrm{~kg} \text { one cigarette may deliver } \\
\text { approximately } 10-30 \mu \mathrm{gg} / \mathrm{Kg}, \text { resulting in a peak plasma level of } 10-50 \mathrm{ng} / \mathrm{mL} .\end{array}$ \\
$\begin{array}{r}\text { A concentration equal to } 50 \mathrm{ng} / \mathrm{mL} \text { can be converted to molarity dividing by nicotine } \\
\text { MW (i.e., } 162)(50 \mathrm{ng} / \mathrm{mL} \text { divided by } 162)=0.309=3.1 \times 10^{-7} \mathrm{M}[9] . \\
\text { This concentration is } 3.6 \text { times lesser than the lethal dose. }\end{array}$ \\
$\begin{array}{r}60 \mathrm{mg} \text { dose means a } 0.8 \mathrm{mg} / \mathrm{kg} \text { in humans equivalent approximately to the amount } \\
\text { found in five cigarettes. }\end{array}$ \\
\hline
\end{tabular}

Heteromeric $n A C h R$ is constituted by $\alpha$ and $\beta$ sub-units assembled around a central pore (the ionic channel) with different stoichiometry, $\alpha 7$ and $\alpha 9$ are homopentamers. Different reviews have described extensively the nature, structure and function of nAChR $[10,11,20]$. The presence of functional CS in non-neuronal cells are actually well established [21,22]. Thus, it is now accepted that ACh acts as a main signaling molecule safeguarding the homeostasis of the entire living organisms from protists to mammals with bacteria and archaea considered as the starting points of the universal phylogenetic tree [23-27]. The CS is involved in nonneuronal cells, considered non excitable cells (i.e., cells that do not generate action potentials), in different functions such as proliferation, neo-angiogenesis, apoptosis, inflammation and immunity $[12,28]$. More than 40 types of cells are present on the lung and $\mathrm{nAChR}$, with a predominance of $\alpha 7-\mathrm{nAChR}$, are expressed in the majority of these cells [17,29-36]. Recently, nicotine has been implicated in the SARS-CoV-2 infection, since, nicotine, through activation of the $\alpha 7-\mathrm{nAChR}$ subtype, induces over-expression of ACE2 [35-37]. ACE2 is the only confirmed SARS-CoV-2 entry receptor [38,39]. SARS-CoV-2 and ACE2 binding allow the virus to enter into a cell through the spike (S) proteins that work in concert with the host cell TMPRSS2. TMPRSS2 cleaves the spike protein of SARS-CoV-2 facilitating membrane fusion. ACE2 relies on the RAS molecular system, ACE2 is a crucial counter-regulatory enzyme to ACE by the breakdown of angiotensin II that is involved in blood pressure regulation and electrolyte homeostasis [40]. Moreover, ACE2 is involved in the bradykinin metabolism in the lungs (i.e., vasodilation and elevation of vascular permeability) [41]. Recent work shows that there is a variable infection gradient in the respiratory tract. Indeed, through high-sensitivity RNA in situ mapping technology, it has been shown that the highest ACE2 expression is detecting in the nose with a decreased expression all through the lower respiratory tract, this observation is paralleled by an outstanding gradient of SARS-CoV-2 infection in proximal (high) versus distal (low) pulmonary epithelial cultures [42]. Current smoking is associated with increased expression of gene for ACE2, and TMPRSS2 [43-46]. It has been shown that airway epithelial cell expression of CHRNA7, encoding $\alpha 7-n A C h R$, is significantly correlated with the expression of ACE2 with a trend towards higher expression in current smokers as compared with former and never smokers [36]. All together these data support the hypothesis that whenever ACE2 expression increases SARS-CoV-2 acquires more gates of entry; thus, exposure to nicotine via smoking or vaping may enhance susceptibility to SARS-CoV-2 infection. Indeed, we have recently shown that nicotine exposure induces rapid and long-lasting increase in gene expression and protein level of ACE2 in low ACE2-expressing human pulmonary adenocarcinoma A549 epithelial cell line, which in turn translates into increased competence for SARS-CoV-2 replication and cytopathic effect [47]. Different epidemiological investigations on relationship between smoking (or nicotine) and SARS-CoV-2 have been published or are available as pre-print, and we have recently extensively reviewed these data [48]. Evidence from these studies is somehow contrasting, and the role of tobacco smoking or vaping is still to be assessed [49-60]. It is possible to suppose the presence of underreporting or misreporting data in recording smoking history at admission, especially to ICU, during the COVID-19 outbreak, when the hospitals are overwhelmed. A recent paper published by Cattaruzza et al. [61] considers 
that the low prevalence among hospitalized patients are partially due to many smokers misclassified as nonsmokers and concludes that tobacco smoking in a dose-dependent model up-regulates ACE2, and this mechanism may explain the high risk of severe COVID-19 in smokers. The annual meeting of ERS (30th Annual Meeting of the European Respiratory Society; September 7-9, 2020 Wien-Österreich) in the section "Epidemiology-Expert view" plans the special section for Monday 7th afternoon "Smoking, nicotine and COVID-19 myths and facts. What is the evidence?" [47]. To explain the role of tobacco smoking on COVID-19 severity and progression, a longitudinal observational study titled COvid19 and SMOking in Italy (COSMO-IT) was designed [62]. The main objective of the COSMO-IT study is to measure and define the role of tobacco smoking and smoking cessation on the severity and progression of COVID-19 in hospitalized patients. Interestingly, a recent population- study, that surveyed 4351 adolescents and young adults aged 13-24 years, highlighted that the effects of vaping may collide with the risk of COVID-19, thus users are at a five-seven-times increased risk of a COVID-19 diagnosis, compared with non-users (data adjusted for major confounders, such as age, sex, and obesity [63]. It has been recently hypothesized that sub-chronic e-cig exposure induces inflammatory response and dysregulated repair/extracellular matrix (ECM) remodeling, which occur through the $\alpha 7$ nicotinic acetylcholine receptor (nAChR $\alpha 7$ ) [64].

On the other hand, Changeux et al. [65] advanced the hypothesis that SARS-CoV-2 may enter the body through neurons of the olfactory system and/or through the lung, and no through ACE2. Changeux et al. [65] proposed nAChR as possible target of SARSCoV-2 and in turn a protective role against SARS-CoV-2 for nicotine. This hypothesis, currently, is not supported by any scientific proof.

In this important scenario for human health, we have explored the cellular and molecular effects induced by nicotine in human bronchial epithelial cells to better understand the nicotine's role in SARS-CoV-2 entry, disease development, and severity. We explored extensively the biological effects induced by nicotine that are important in SARS-CoV-2 infection, effects not explored in our previous paper [35].

\section{Results}

HBEpC expresses functional $\alpha 7-\mathrm{nAChR}$ that increases both after short time $(1 \mathrm{~h})$ and continuous ( 1 treatment every $48 \mathrm{~h}$ for a total of 16 passages) exposure to nicotine at $1 \times 10^{-7} \mathrm{M}$ [35]. HBEpC expresses also ACE2 that, after nicotine treatment, increases concurrently with the increment in $\alpha 7-n A C h R$ proteins [35]. On the contrary, si-mRNA$\alpha 7$-HBEpC that does not express $\alpha 7-n A C h R$ after nicotine treatment does not show any increase in ACE2 proteins [35]. The effect of nicotine $1 \times 10^{-7} \mathrm{M}$ on cell viability was evaluated both in the HBEpC and si-mRNA- $\alpha 7-\mathrm{HBEpC}$ cells treated for $1 \mathrm{~h}$. Cells were counted $48 \mathrm{~h}$ after drug removal. We found that nicotine enhances cell viability only in wild-type cells (Figure 1A).

Cell proliferation was evaluated exposing HBEpC and si-mRNA- $\alpha 7-\mathrm{HBEpC}$ to nicotine over time (from zero to $96 \mathrm{~h}$ ): Nicotine was added every $48 \mathrm{~h}$. Nicotine significantly increased cell proliferation, however, when $\alpha 7-n A C h R$ was silenced, cells grow more slowly and nicotine failed to induce cell proliferation (Figure 1B). The doubling time of HBEpC, under our experimental conditions is $44 \pm 2 \mathrm{~h}$, when cells were exposed continuously to $1 \times 10^{-7} \mathrm{M}$ nicotine, the doubling time was $25 \pm 1 \mathrm{~h}$ with a reduction of $43.18 \%$. The doubling time of si-mRNA- $\alpha 7-\mathrm{HBEpC}$ was higher than $96 \mathrm{~h}$ and remained the same also after continuous treatment with nicotine (Figure 1B).

Ki67 expression, a marker of proliferation, was evaluated by ELISA in both wild type and silenced cells after treatment with nicotine for $48 \mathrm{~h}$. HeLa cells, an immortal cancer cell line with a doubling time of $\sim 26.67 \mathrm{~h}$, were used as positive control (Figure 2A). The amount of Ki67 in HBEpC cells was $878.24 \pm 35 \mathrm{pg} / \mathrm{mL}$ in the absence of nicotine, increasing by $117.13 \%$ in presence of nicotine $(1,907.05 \pm 28 \mathrm{pg} / \mathrm{mL})$ with respect to untreated cells. Thus, when nicotine was present the level of Ki67 was very similar to that detected in HeLa cells $1907.05 \pm 28 \mathrm{pg} / \mathrm{mL}$ versus $2,149.10 \pm 73 \mathrm{pg} / \mathrm{mL}$ ). si-mRNA- $\alpha 7-$ HBEpC showed low level of 
Ki67 that did not increase after nicotine exposure (212.65 \pm 13.3 and $152.13 \pm 31.8$, respectively). These findings were confirmed also in Western blotting experiments (Figure 2C,D).
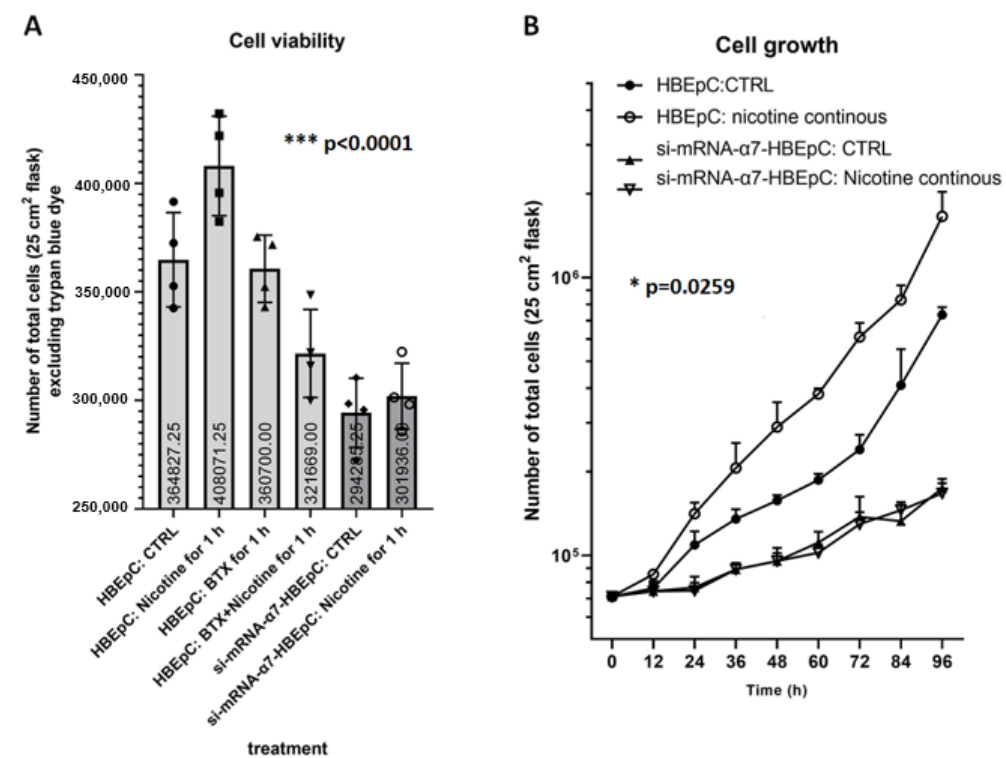

Figure 1. Cell viability (A) and cell proliferation (B) induced by nicotine in HBEpC and/or si-mRNA- $\alpha 7$ HBEpC viability. (A): For cell viability, 7500 cells $/ \mathrm{cm}^{2}$ are plated in T25 flask (total cell number 187,000) and treated with nicotine $1 \times 10^{-7} \mathrm{M}$, after $1 \mathrm{~h}$ cells are washed three times in PBS $\mathrm{Ca}^{2+} \mathrm{and} \mathrm{Mg}^{2+}$ free and then incubated in drug-free medium for additionally $48 \mathrm{~h}$. Then, cells (detached or floating) are counted after staining with trypan blue dye. (B): For cell proliferation 7500 cells $/ \mathrm{cm}^{2}$ are plated in T25 flask and treated with nicotine every $48 \mathrm{~h}$. Cells are detached and viable cells are counted every $12 \mathrm{~h}$. Experiments are performed at least two times in triplicate. Statistical significance is analyzed with one-way ANOVA with multiple-comparison and post hoc test with Bonferroni correction.

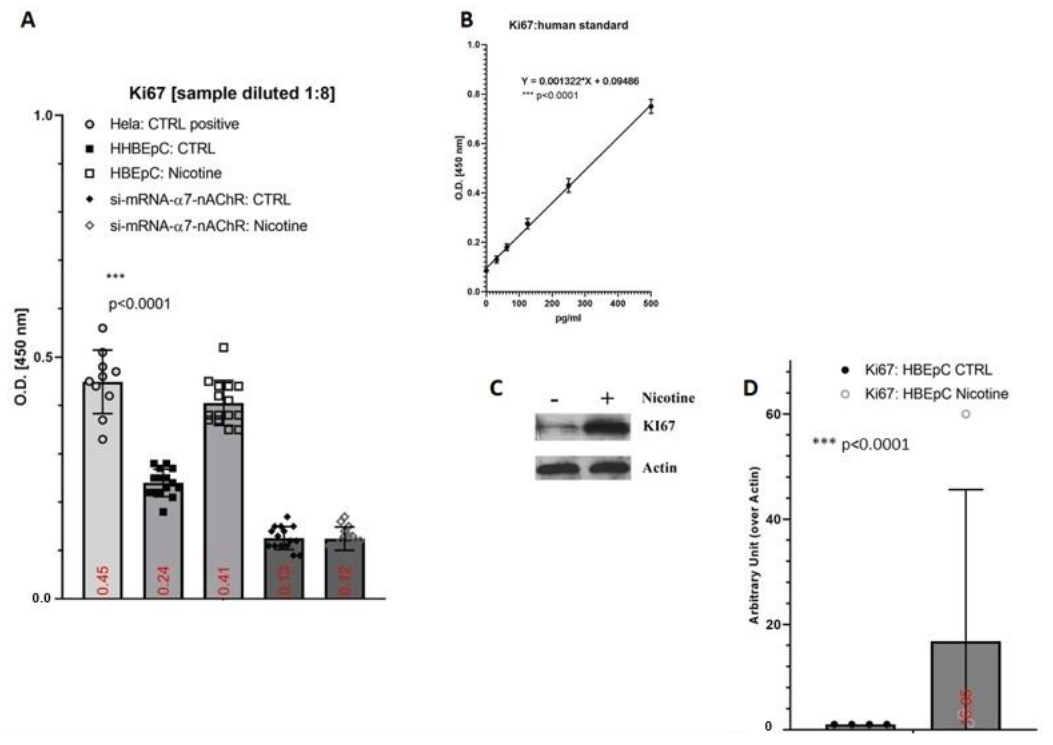

Figure 2. Expression of Ki67 induced by nicotine in HBEpC and/or si-mRNA- $\alpha 7-\mathrm{HBEpC}$. (A): ELISA experiments; (B): regression equation linearity, performed with Prism; (C): Western blotting, (D): densitometric analysis. Statistical significance is analyzed with one-way ANOVA with multiplecomparison and post hoc test with Bonferroni correction. Experiments are performed at least two times in triplicate. In the Supplementary Materials, raw data of Western blotting are reported. 
HBEpC has a finite lifetime in cell culture before dying, thus, starting from the 16th passages $\mathrm{HBEpC}$ grew more slowly than their counterpart growing in the continuous presence of nicotine. At the 24th HBEpC stopped to grow and divide while nicotine-treated HBEpC retained the ability to divide and grow (data not shown). The extent of senescence is correlated with the increased activity of the SA- $\beta-$ Gal. Accordingly, to cell growth data, SA- $\beta-G a l$ levels started to increase for the 8 th passage reaching the maximum level the 24 th passage, in a time-dependent manner. In the presence of nicotine, SA- $\beta$-Gal level started to increase at the 16th passage, not as much as in untreated cells $(-37.7 \% p<0.001)$, and at the 24 th, its amount was $28.56 \%$ lower than in untreated cells $(p<0.001)$ (Figure 3$)$.

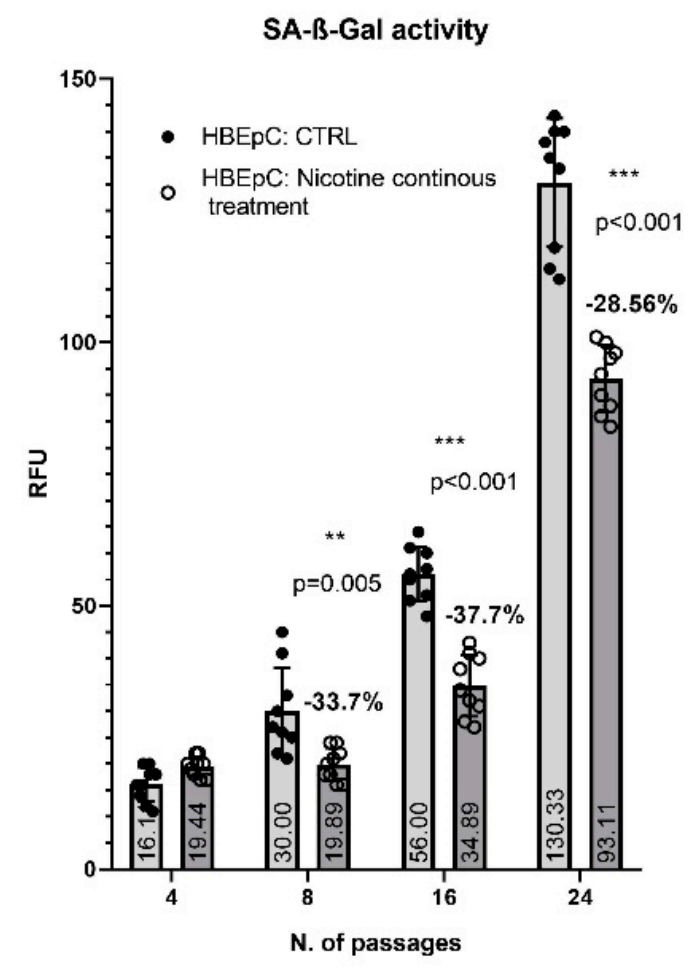

Figure 3. SA- $\beta$-Gal in HBEpC exposed continuously to nicotine. Experiments are performed at least two times in triplicate.

Moreover, we found that following $48 \mathrm{~h}$ nicotine treatment, the basal levels of $\mathrm{Ca}^{2+}$ in HBEpC significantly increased ( $p=0.0004)$ from $3.9 \pm 0.3 \mathrm{mM}$ to $7.9 \pm 0.2 \mathrm{mM}$, but no in the silenced cells $(2.6 \pm 0.3$ versus $2.9 \pm 0.4 \mathrm{mM})$ (Figure 4$)$.

Under the same experimental condition, nicotine decreased the amount of ATP in $\mathrm{HBEpC}$ from $6.04 \pm 0.14$ to $0.63 \pm 0.12 \mathrm{nM}(p=0.0003)$ (Figure 5).

We evaluated also the expression of human EGFR and pEGFR in $48 \mathrm{~h}$ nicotine treated HBEpC, which reached the level of $0.56 \pm 0.11$ and $1.33 \pm 0.31 \mathrm{ng} / \mathrm{mL}$, increasing by $138 \%$ with respect to untreated cell (Figure 6A,B) and $0.58 \pm 0.08 \mathrm{IU} / \mathrm{mL}$ and $1.14 \pm 0.09 \mathrm{IU} / \mathrm{mL}$ with an increase of $97.2 \%$, respectively (Figure 6 C,D). si-mRNA- $\alpha 7-H B E p C$ showed a low level of both EGFR and pEGFR that did not increase after nicotine exposure (Figure 6).

Nicotine decreased the amount of p53 and phoshop53 proteins. In the ELISA test, p53 was reduced by $24.42 \%$ after $1 \mathrm{~h}$ and by $53.49 \%$ after $48 \mathrm{~h}$, whereas phospho-p53 was reduced by $43.24 \%$ both after 1 and $48 \mathrm{~h}$. The Western blotting confirms the reduction of p53 in a time-dependent manner $\left(400 \mu \mathrm{M} \mathrm{H}_{2} \mathrm{O}_{2}\right.$ positive control) (Figure 7).

Nicotine increased the amount of phosho-p38 proteins after $1 \mathrm{~h}$ of treatment (Figure 8A,B). The amount of phosho-p38 in untreated cells was $10.70 \pm 1.11 \mathrm{U} / \mathrm{mL}$ and in treated cells was $24.2 \pm 2.43 \mathrm{U} / \mathrm{mL}$ with an increase of $126 \%$. No variation of p38 was observed (Figure 8A,C).

Nicotine treatment for $48 \mathrm{~h}$ induces EMT characterized by inhibition of E-Cadherin expression and up-regulation of mesenchymal markers such as FN and Vimentin (Figure 9). 
A

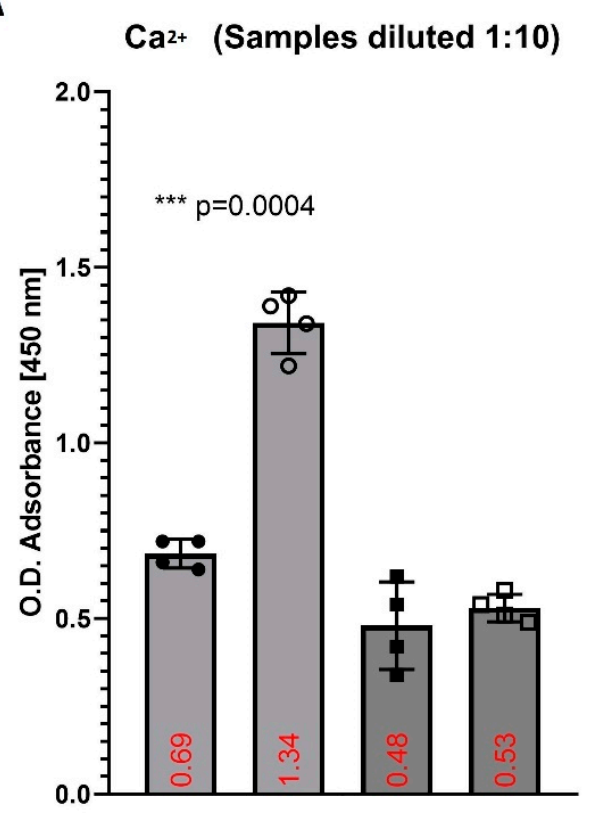

B

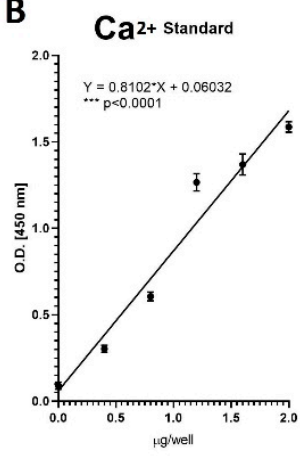

- HBEpC: $\mathrm{Ca}^{2+} \mathrm{CTRL}$

- HBEpC: $\mathrm{Ca}^{2+}$ Nicotine

- si-mRNA-a7-HBEpC: $\mathrm{Ca}^{2+} \mathrm{CTRL}$

口 si-mRNA-a7-HBEpC: $\mathrm{Ca}^{2+}$ Nicotine

Figure 4. Evaluation of intracellular $\mathrm{Ca}^{2+}$ after exposure to nicotine for $48 \mathrm{~h}$ in $\mathrm{HBEpC}$ and/or si-mRNA- $\alpha$ 7-HBEpC. (A): ELISA experiments; (B): regression equation linearity, performed with Prism. Statistical significance is analyzed with one-way ANOVA with multiple-comparison and post hoc test with Bonferroni correction. Experiments are performed at least two times in triplicate.

A

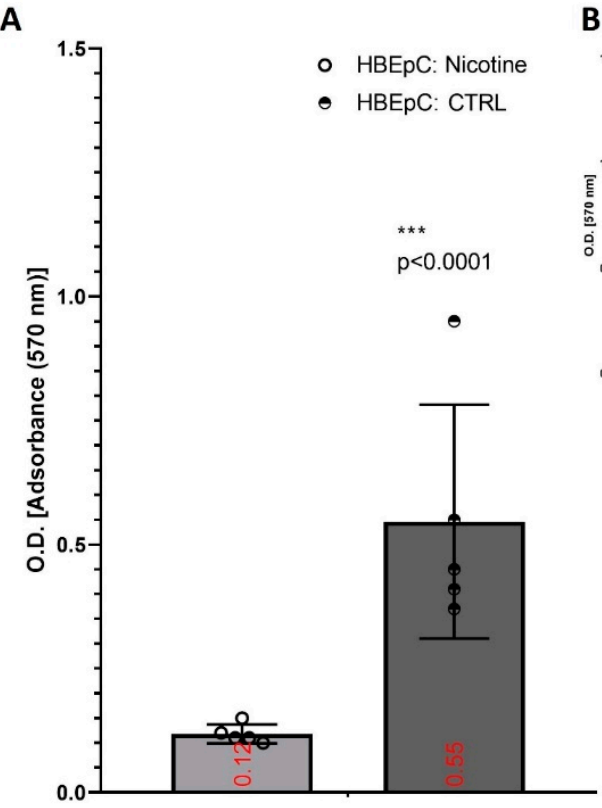

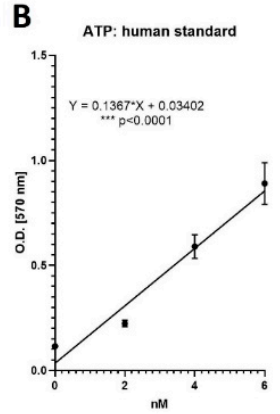

Figure 5. Evaluation of intracellular ATP after exposure to nicotine for $48 \mathrm{~h}$ in HBEpC. (A): ELISA experiments; (B): regression equation linearity, performed with Prism. Experiments are performed at least two times in triplicate. 

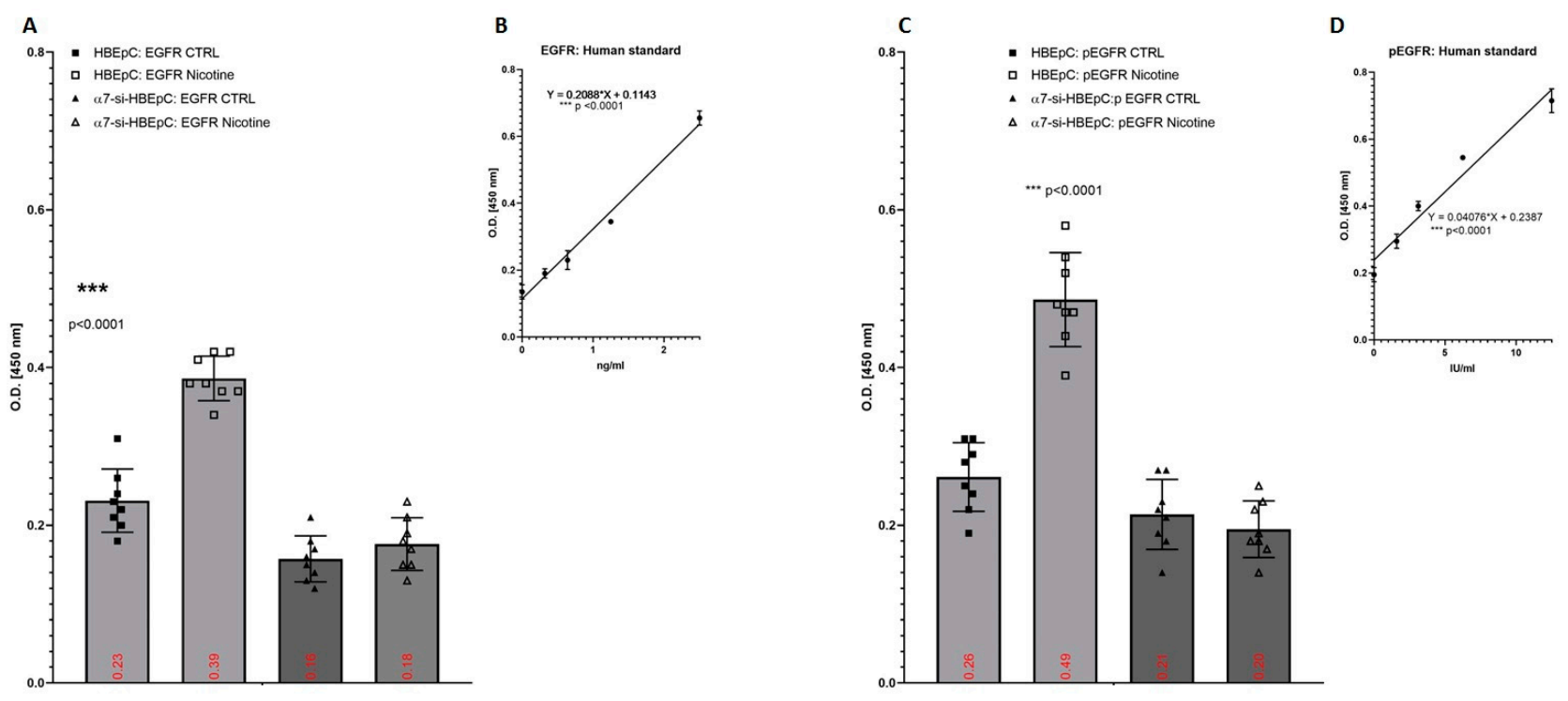

Figure 6. Expression of EGF and p-EGFR after exposure to nicotine for $48 \mathrm{~h}$ in HBEpC. (A): ELISA experiments for EGFR; (B): regression equation linearity for EGFR, performed with Prism; (C): ELISA experiments for p-EGFR; (D): regression equation linearity for p-EGFR, performed with Prism. Statistical significance is analyzed with one-way ANOVA with multiple-comparison and post hoc test with Bonferroni correction. Experiments are performed at least two times in triplicate.
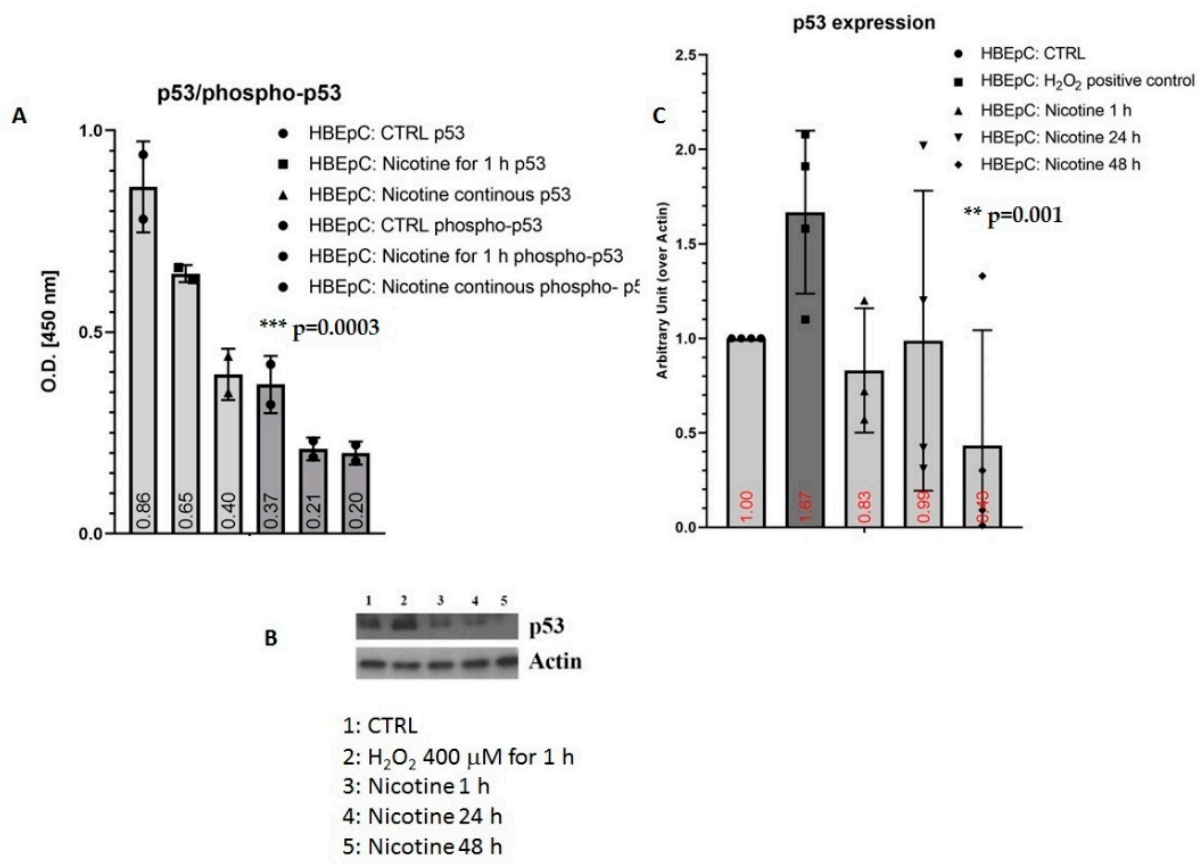

Figure 7. Induction of p53 and phospho-p53 induced by nicotine in HBEpC. (A): ELISA assay. (B): Western blotting experiments, (C): densometric analysis. Experiments are performed at least two times in triplicate. Statistical significance is analyzed with one-way ANOVA with multiplecomparison and post hoc test with Bonferroni correction. In the Supplementary Materials, raw data of Western blotting are reported. 

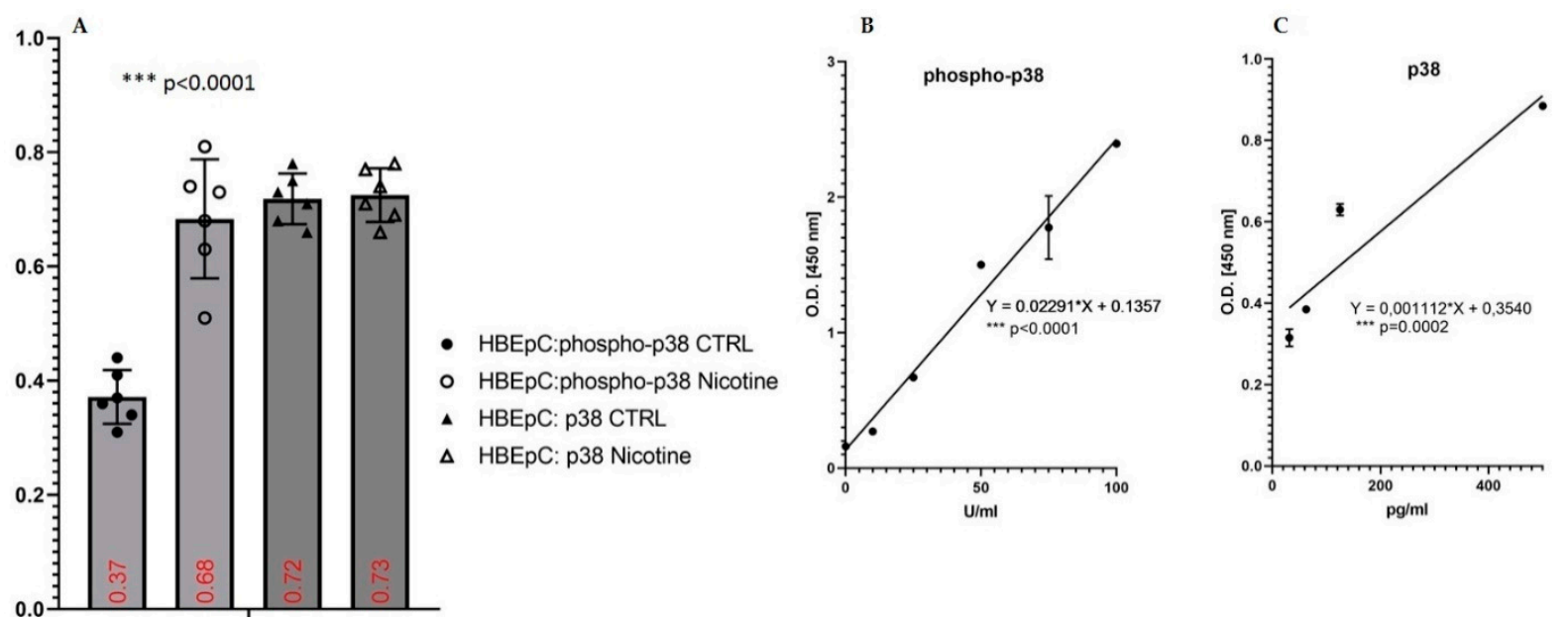

Figure 8. Induction of phospho-p38 and p38 by nicotine in HBEpC. (A): ELISA experiments; (B): regression equation linearity for phosphor-p38; (C): regression equation linearity for phosphor-p38performed with Prism. Statistical significance is analyzed with one-way ANOVA with multiple-comparison and post hoc test with Bonferroni correction. Experiments are performed at least two times in triplicate.
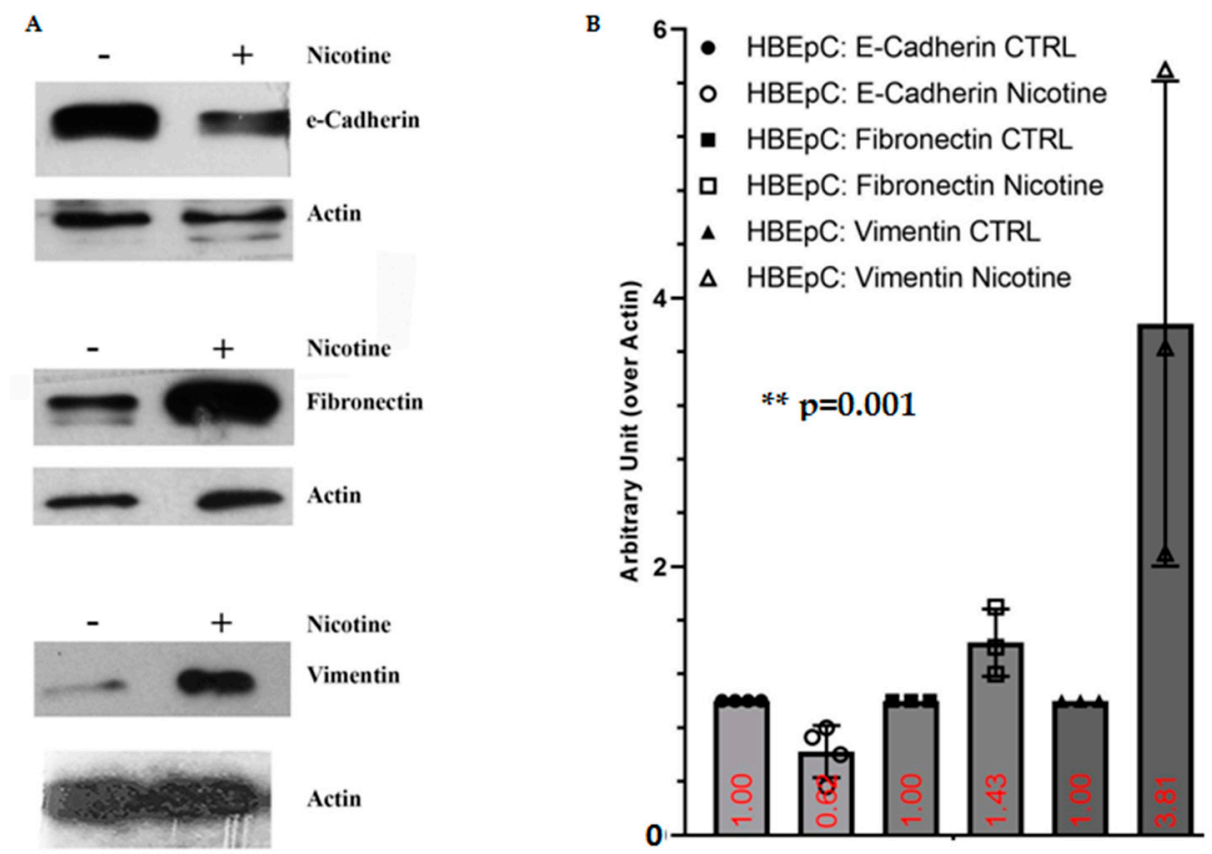

Figure 9. EMT induced by nicotine in HBEpC. (A): Western blotting; (B): densitometric analysis. Statistical significance is analyzed with one-way ANOVA with multiple-comparison and post hoc test with Bonferroni correction. Experiments are performed at least two times in triplicate. In the Supplementary Materials, raw data of Western blotting are reported.

HBEpC can migrate, although with a lower extent than HeLa cells (positive control known to be able to migrate Figure 10A). Nicotine exposure for $48 \mathrm{~h}$ in complete Bronchial/Tracheal Epithelial Cell Growth Medium significantly $(p<0.0001)$ increased the migration ability $(+74.6 \%)$. The effect was strictly dependent on $\alpha 7-\mathrm{nAChR}$, since simRNA- $\alpha 7-H B E p C$ abolished their ability to migrate (Figure 10B). 
A

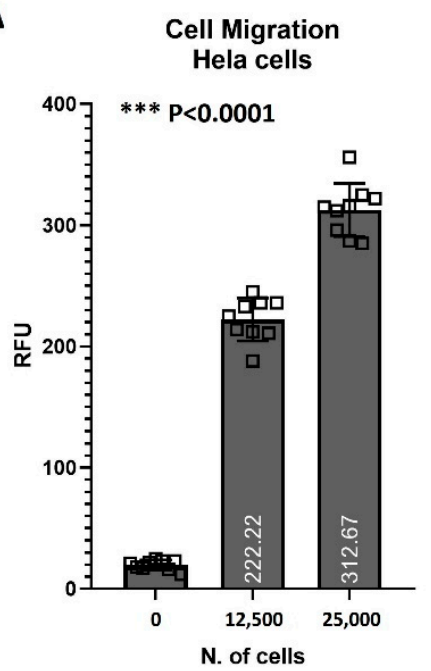

B

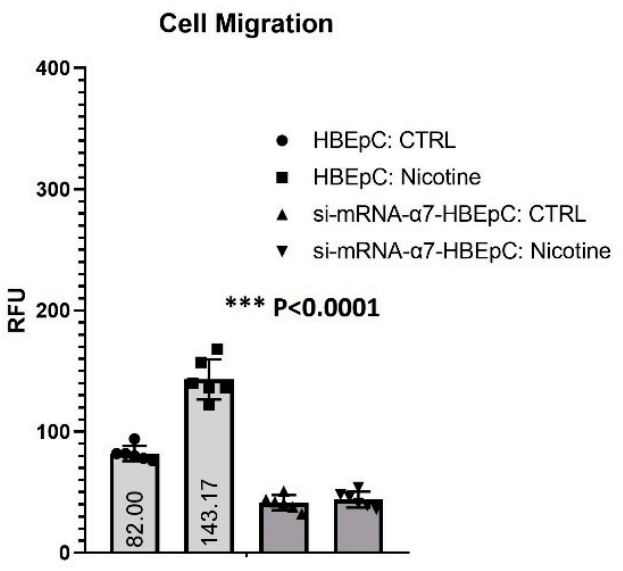

Figure 10. Cell migration to nicotine for $48 \mathrm{~h}$ in HBEpC and/or si-mRNA- $\alpha 7-$ HBEpC. HeLa cells are positive control. (A) HeLa positive control. (B): Cell migration h in HBEpC and/or si-mRNA- $\alpha 7-$ HBEpC. Statistical significance is analyzed with one-way ANOVA with multiple-comparison and post hoc test with Bonferroni correction. Experiments are performed at least two times in triplicate.

HBEpC produce VEGF. nicotine exposure for $48 \mathrm{~h}$ significantly $(p<0.0001)$ increases the release of VEGF namely from $696.28 \mathrm{pg} / \mathrm{mL}$ to $1,409.9 \mathrm{pg} / \mathrm{mL}$ with $102 \%$. The effect is strictly dependent on $\alpha 7$-nAChR, since in si-mRNA- $\alpha 7-$ HBEpC no increase is observed (Figure 11).

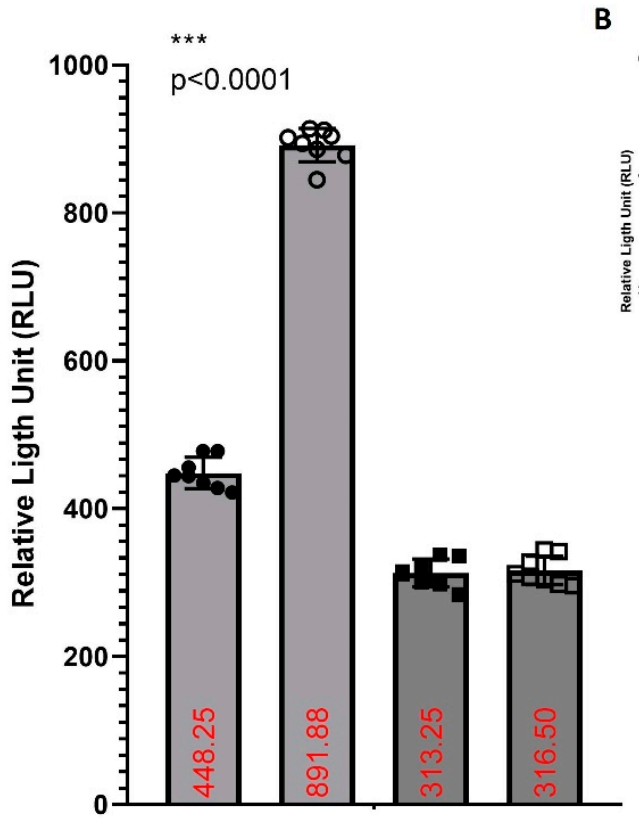

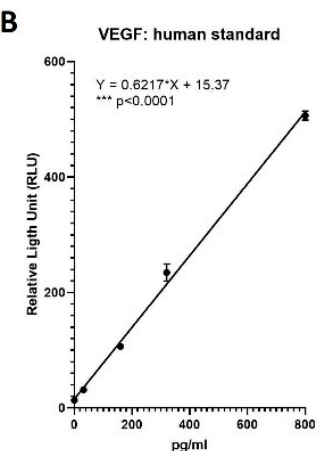

- HBEpC: VEGF CTRL

- HBEpC: VEGF Nicotine

- si-mRNA- $\alpha 7-H B E p C: V E G F C T R L$

a si-mRNA- $\alpha 7-H B E p C: V E G F$ Nicotine

Figure 11. Induction of VEGF by nicotine in HBEpC and/or si-mRNA- $\alpha 7-H B E p C$. (A): ELISA experiments; (B) regression equation linearity for VEGFR. Statistical significance is analyzed with one-way AOVA with multiple-comparison and post hoc test with Bonferroni correction. Experiments are performed at least two times in triplicate.

Anchorage-dependent growth (ADG) is mandatory for non-transformed epithelial cell survival. Thus, HBEpC is not able to grow when seeded onto soft agar (Figure 12A). HBEpC cells at the 16th passage (one passage every $48 \mathrm{~h}$ ) under the continuous presence of nicotine showed the ability to grow independently of the substrate (Figure 12). However, treated cells in comparison with HeLa cells (positive control) grew $\sim 62 \%$ less. This effect 
was not observed in si-mRNA- $\alpha 7-\mathrm{HBEpC}$ that grow similarly to NIH3T3 (negative control or untreated $\mathrm{HBEpC})$.

A

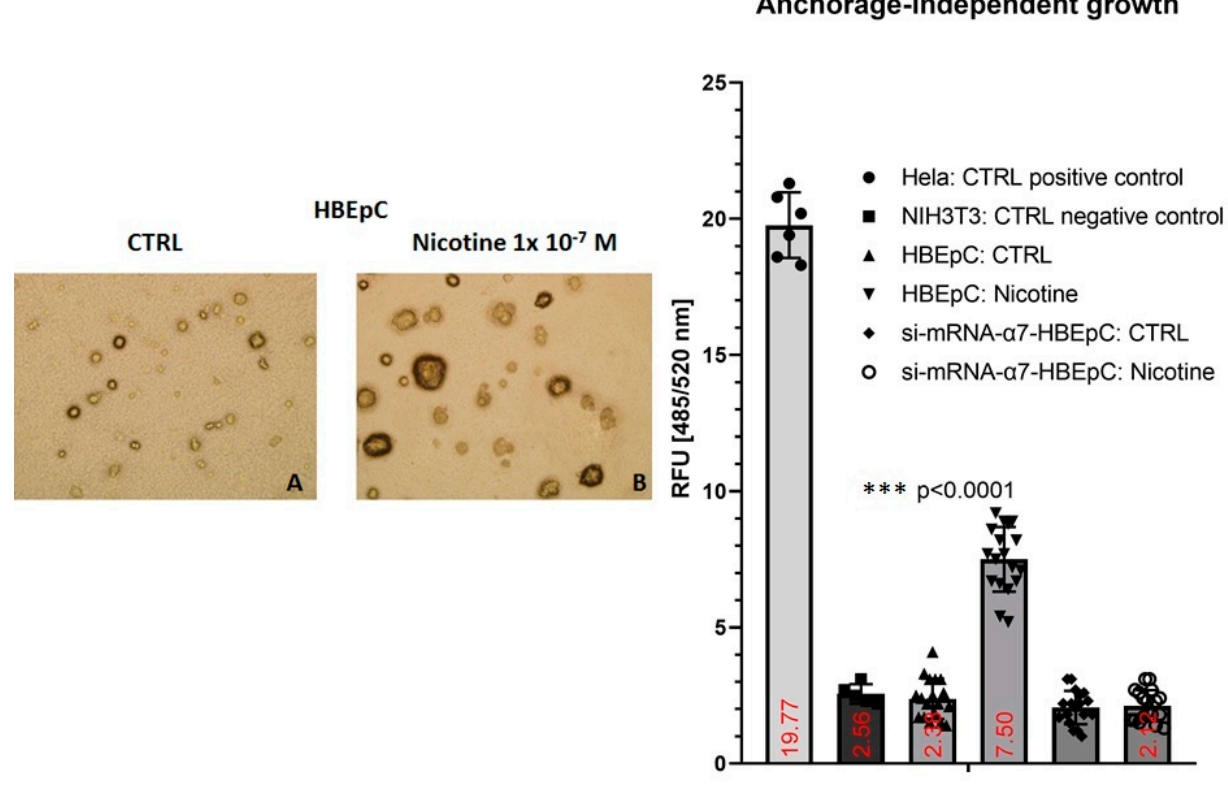

Figure 12. Anchorage-independent growth induced by nicotine in HBEpC. HeLa cells are positive control and NIH3T3 the negative. (A): Representative picture of HBEpC cloned on soft agar. (B): Cloned cells. Statistical significance is analyzed with one-way ANOVA with multiplecomparison and post hoc test with Bonferroni correction. Experiments are performed at least two times in triplicate.

\section{Discussion}

In this work, we report data to support our hypothesis that nicotine may be involved in the processes facilitating SARS-CoV-2 infection [35]. We have previously shown in HBEpC that nicotine enhances the expression levels of $\alpha 7$-nAChR and ACE2 through MAPK/ERK activation [35]. Moreover, nicotine increases SARS-CoV-2 replication, transcription of SARS-CoV-2 viral proteins, and SARS-CoV-2 cytopathic effect [47]. Thus, it is reasonable to assume that the entrance and replication of SARS-CoV-2 may be caused by the mechanisms related to $\mathrm{nAChR}$ mediated-signaling, as previously hypothesized [35,37]. In this work, our data show that nicotine, under conditions mimicking the human exposure in smokers (i.e., concentration and exposure time), through induction of $\alpha 7-\mathrm{nAChR}$ induces: (i) increase in cell viability; (ii) cell proliferation; (iii) Ki67 over-expression; (iv) phosphop38 up-regulation; (v) EGFR and pEGFR over-expression; (vi) more basal $\mathrm{Ca}^{2+}$ concentration; (vii) reduction of ATP production; (viii) decreased level of p53 and phosphor-p53; (ix) delayed senescence; (x) VEGF increase; (xi) EMT and consequent; (xii) enhanced migration; and (xiii) ability to grow independently of the substrate. Some of these characteristics are typical of cancer cells [66]. All these effects are strictly dependent by $\alpha 7-n A C h R$. Thus, when $\alpha 7$-(si-mRNA- $\alpha 7-\mathrm{HBEpC}$ ) or $\alpha 4$-nAChR were silenced (si-mRNA- $\alpha 4-\mathrm{HBEpC}$ ) no ACE2 upregulation was observed (see Supplementary Materials for si-mRNA- $\alpha 4-\mathrm{HBEpC}$ ).

These results may help to understand the causal link between exposure to nicotine and the progression and severity of SARS-CoV-2 infection. Table 2 shows the effects induced by nicotine, the effects induced by SARS-CoV-2, by SARS-CoV, and MERS-CoV as well as by non-tumorigenic virus infection. 


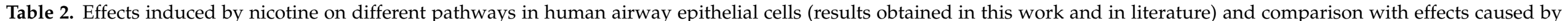
SARS-CoV-2, SARS-CoV, MERS-CoV and by non-tumorigenic virus infection on the same pathways.

\begin{tabular}{|c|c|c|c|c|}
\hline & $\begin{array}{l}\text { Effects Induced by Nicotine in Human Airway Epithelial Cells } \\
\text { [References] }\end{array}$ & $\begin{array}{l}\text { Effects Induced by SARS-CoV-2 } \\
\text { [References] }\end{array}$ & $\begin{array}{l}\text { Effects Induced by SARS-CoV or MERS-CoV } \\
\text { [References] }\end{array}$ & $\begin{array}{l}\text { Effects Induced by Non-Tumorigenic Virus Infection } \\
\text { [References] }\end{array}$ \\
\hline \multicolumn{5}{|c|}{$\alpha 7$-nAChR Down-Stream Pathways } \\
\hline$\alpha 7$-nAChR & Increase in HBEpC and A549 cells $[35,47]$ & $\begin{array}{l}\text { Silico experiments show the possibility that SARS-CoV-2 may interact with } \\
\text { nAChR [67,681. Nemantine, } 27 \text {-nAChR antagonist, decreases ACE2 and } \\
\text { reduces oxidative stress and inflammation. Nemantine may reduce } \\
\text { SARS-CoV-2 virulence [69]. }\end{array}$ & & 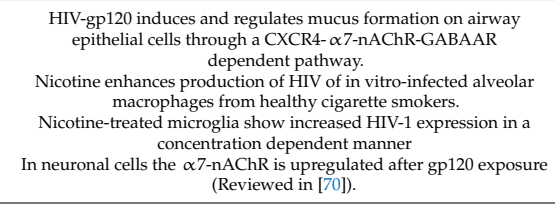 \\
\hline ACE2 & $\begin{array}{l}\text { Increase in HBEpC and A549 cells } \\
{[35,47]} \\
\text { Correlation between } \alpha 7 \text {-nAChR and ACE2 [36] } \\
\text { and reviewed in [71] }\end{array}$ & $\begin{array}{l}\text { Bioinformatics modeling and in vitro experiments indicate that AARS-CoV-2 } \\
\text { utilizes ACE2 as a receptor to gain entry into human cells } 339] \text {. }\end{array}$ & 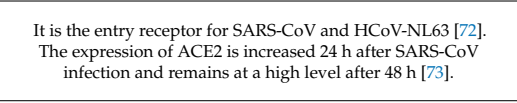 & \\
\hline ERK/MAPK, Phospho-p38 & $\begin{array}{l}\text { Increase in HBEpC } \\
\text { (this work and } \\
{[35,4] \text { and reviewed in [12]] }}\end{array}$ & 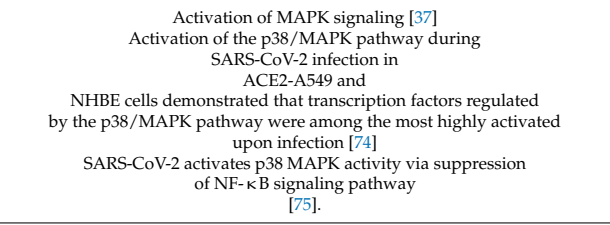 & $\begin{array}{l}\text { SARS-CoV was shown to express proteins that directly } \\
\text { upregulate } 38 \text { MAPK in vitro } \\
\text { [76]. }\end{array}$ & \\
\hline \multicolumn{5}{|c|}{ Cell Proliferation and Cell Cytotoxicity } \\
\hline Cell proliferation & $\begin{array}{l}\text { Increase in HBEpC and A549 cells } \\
\text { (this work and } \\
[35,4] \text { and reviewed in }[12,77])\end{array}$ & 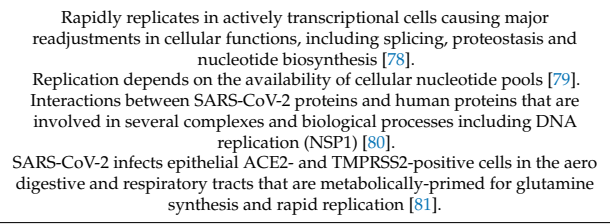 & & \\
\hline Cell Cytotoxicity & $\begin{array}{l}\text { Decrease in HBEpC and A549 cells } \\
\text { (this work and }[35,47] \text { ) }\end{array}$ & & & \\
\hline Doubling time & $\begin{array}{l}\text { Decrease in HBEpC and A549 cells } \\
\text { (this work and[35,47]) }\end{array}$ & $\begin{array}{l}\text { A significant increase in the fraction of cells in } S \text { phase and at the } \mathrm{G}_{2} / \mathrm{M} \\
\text { transition and a decrease in the fraction of cells in } \mathrm{G}_{0} / \mathrm{G}_{1} \text { phase were } \\
\text { observed }[74] \text {. }\end{array}$ & & \\
\hline Ki67 & $\begin{array}{c}\text { Increase in HBEpC } \\
\text { (this work) }\end{array}$ & & & \\
\hline EGFR/pEGFR & $\begin{array}{l}\text { Increase in } \mathrm{HBEpC} \\
\text { (this work and [82,83]) }\end{array}$ & Pathways of EGFR is influenced by SARS-CoV-2 [84]. & $\begin{array}{l}\text { In human bronchial epithelial cells exposed to SARS-CoV, for 12, } \\
24 \text {, and } 48 \mathrm{~h} \text { the expression of EGFR gene is high } 12 \mathrm{~h} \text { after the } \\
\text { infection and then decreases after } 24-48 \mathrm{~h}[85] \text { ]. }\end{array}$ & \\
\hline p53/phospho-p53 & $\begin{array}{l}\text { Decrease in HBEpC and A549 cells } \\
\text { (this work and }[35,47,86,8] \text { ) }\end{array}$ & & $\begin{array}{l}\text { p53 works as an anti-viral factor inhibiting viral replication thus } \\
\text { in cells lacking p53 the rate of virus replication is higher than in } \\
\text { cells expressing p53 [88]. }\end{array}$ & 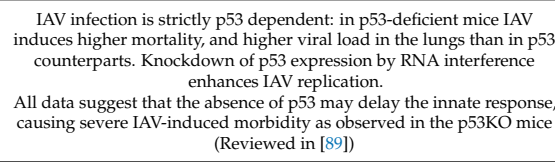 \\
\hline SA- $\beta$-Gal activity & $\begin{array}{l}\text { Delay in senescence } \\
\text { (this work) }\end{array}$ & & & \\
\hline
\end{tabular}


Table 2. Cont.

\begin{tabular}{|c|c|c|c|c|}
\hline & $\begin{array}{l}\text { Effects Induced by Nicotine in Human Airway Epithelial Cells } \\
\text { [References] }\end{array}$ & $\begin{array}{l}\text { Effects Induced by SARS-CoV-2 } \\
\text { [References] }\end{array}$ & $\begin{array}{l}\text { Effects Induced by SARS-CoV or MERS-CoV } \\
\text { [References] }\end{array}$ & $\begin{array}{l}\text { Effects Induced by Non-Tumorigenic Virus Infection } \\
\text { [References] }\end{array}$ \\
\hline \multicolumn{5}{|c|}{ Mitochondrial Dysfunction } \\
\hline & $\begin{array}{l}\text { Induction in HBEpC } \\
\text { (this work and [90-92]) }\end{array}$ & $\begin{array}{l}\text { Down regulation of genes in the mitochondrial and electron transport chain } \\
\text { processes. Similar alterations are observed in infected human } \\
\text { nasopharyngeal samples, used as control [93]. }\end{array}$ & & \\
\hline ATP & $\begin{array}{l}\text { Decrease in HBEpC } \\
\text { (this work and } \\
\text { [92]]) }\end{array}$ & & & \\
\hline $\mathrm{Ca}^{2+}$ & Increase basal $\mathrm{Ca}^{2+}$ in $\mathrm{HBEPC}$ (this work and $[94,95]$ ) & & 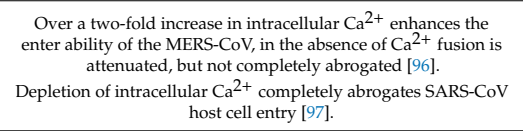 & $\begin{array}{l}\text { High levels of cytosolic } \mathrm{Ca}^{2+} \text { concentrations and influx of } \mathrm{Ca}^{2+} \text { into } \\
\text { mitochondria sustain viral Iepliciction of different respiratory viruses } \\
\text { such as RSV } \mathrm{RS} \text {, MV and } \mathrm{RV}[97,98] \text {. }\end{array}$ \\
\hline \multicolumn{5}{|c|}{ EMT } \\
\hline & $\begin{array}{l}\text { Nicotine induced EMT in different epithelial cells (Reviewed in [12,83] } \\
\text { and [99]) }\end{array}$ & $\begin{array}{l}\text { SARS-COV-2 infection shifts cells to a more mesenchymal phenotype, } \\
\text { which is confirmed by downregulation of EPCAM expression following } \\
\text { viral infection [81]. }\end{array}$ & & \\
\hline E-Cadherin & $\begin{array}{l}\text { Decrease of E-cadherin } \\
\text { (this work and }[99,100] \text { ) }\end{array}$ & & & \\
\hline Fibronectin & $\begin{array}{l}\text { Increase FN } \\
\text { (this work and [101,102]) }\end{array}$ & $\begin{array}{l}\text { Bioinformatics analysis shows that FN interacts with ACE2, the mRNA and } \\
\text { protein of this molecule are more expressed in lung epithelial cells after } \\
\text { AARS-CoV-2 infection [103]. }\end{array}$ & & \\
\hline Vimentin & 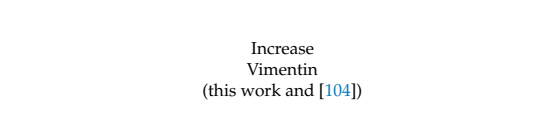 & & $\begin{array}{l}\text { Important role for Vimentin in SARS-CoV virus entry through } \\
\text { interaction with its S protein [105] in the SARS-COV-permissive } \\
\text { cell line Vero E6. } \\
\text { In these celly the therresson of extraclluar Vimentin is } \\
\text { upregulated after virus interaction and enhances its } \\
\text { delivery to ACE2. }\end{array}$ & \\
\hline Cell Migration & $\begin{array}{l}\text { Increase cell migration } \\
\text { (this work and [12]). }\end{array}$ & & & \\
\hline Anchorage independent growth & $\begin{array}{l}\text { Increase slowly } \\
\text { (this work and [106]) }\end{array}$ & & & \\
\hline \multicolumn{5}{|c|}{ Neo-Angiogenesis } \\
\hline & $\begin{array}{l}\text { Increase } \\
\text { (this work and [83,10]]) }\end{array}$ & $\begin{array}{l}\text { SARS-CoV-2 infection show the presence of IA as well as of } \\
\text { conventional SA [107]. }\end{array}$ & & 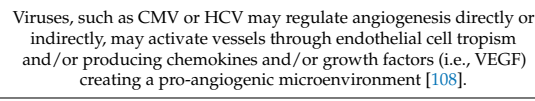 \\
\hline VEGF & $\begin{array}{l}\text { Increase VEGF } \\
\text { (this work and [83,109]) }\end{array}$ & $\begin{array}{l}\text { Bioinformatics analysis shows that VEGF interacts with ACE2, the mRNA } \\
\text { and protein of this moleculue are more expressed in lung epithelial cells after } \\
\text { ARRS-CoV-2 infection [103]]. }\end{array}$ & & \\
\hline \multicolumn{5}{|c|}{ Effects Induced by Nicotine in SARS-CoV-2 Infection } \\
\hline \multicolumn{5}{|c|}{ Increase SARS-CoV-2 replication in A549 cells [47]. } \\
\hline & & Increase the transcription of SARS-CoV-2 2 viral proteins in A549 cells [47]. & & \\
\hline & & Increase SARS-CoV-2 cytopathic effect in A549 cells [47]. & & \\
\hline
\end{tabular}


HBEpC is derived from the surface epithelium of unaffected (normal) human bronchi consequently they have a finite lifetime in cell culture before dying, similarly to all cultures of adult human alveolar epithelial type II (AT2) cells which are characteristically shortlived and feeder-dependent [110]. As cells approach the limit, commonly known as the "Hayflick limit" [111], cells start to show different signs of aging and then die. In the presence of nicotine, $\mathrm{HBEpC}$ can grow for a longer time (more than 24 passages equal to 48 days) also independently of the substrate (soft agar). In brief, nicotine prevents or delays cell death by making more functional cells available for a possible viral infection. It has been shown that SARS-CoV-2 rapidly replicates in actively transcriptional cells causing major readjustments in cellular functions, including splicing, proteostasis, and nucleotide biosynthesis [78]. Indeed, Coronavirus replication depends on the availability of cellular nucleotide pools [79], and consequently of a proliferating and viable cell. SARS-CoV-2 protein interaction map [112] highlights interactions between SARS-CoV-2 proteins and human proteins that are involved in several complexes and biological processes including DNA replication (i.e., NSP1). The SARS-CoV-2 NSP1 is known to suppress host gene expression by ribosome association [80].

Several data imply p53 wild-type in the viral life cycle of non-tumor-promoting viruses, indeed some viruses need active p53 for their efficient replication, whereas others need reduction/inhibition of its activity. The IAV infection is strictly p53-dependent: in p53deficient mice, IAV induces higher mortality, and higher viral load in the lungs than in the p53 counterparts. The knockdown of p53 expression by RNA interference enhances IAV replication. All data suggest that the absence of p53 may delay the innate response, causing severe IAV-induced morbidity as observed in the p53KO mice [89]. In SARS-CoV disease, p53 works as an anti-viral factor inhibiting viral replication thus in cells lacking p53 the rate of virus replication is higher than in cells expressing p53 [88].

A computational analysis of microRNA-mediated interactions in SARS-CoV-2 infection revealed that among different affected pathways that of the of EGFR (17 genes) is influenced by SARS-CoV-2 [84]. It has been shown that in human bronchial epithelial cells treated with SARS-CoV, for 12, 24, and $48 \mathrm{~h}$, the expression of EGFR gene is increased $12 \mathrm{~h}$ after the infection and then decreases after 24-48 h [85]. SARS-CoV-2 Spike and SARS-CoV Spike bind with similar affinities to human ACE2 [113].

More $\mathrm{Ca}^{2+}$ elevation and reduced ATP production suggest a mitochondrial dysfunction induced by nicotine. As well known, mitochondria express $\alpha 7-n A C h R ;$ nicotine in isolated mitochondria decreases the consumption of $\mathrm{O}_{2}$ and the mitochondrial membrane potential whereas in intact cells the consumption of $\mathrm{O}_{2}$, and the $\mathrm{Ca}^{2+}$ levels increase. The reduction of the mitochondrial membrane potential is linked to ATP reduction [92]. High levels of cytosolic $\mathrm{Ca}^{2+}$ concentrations and influx of $\mathrm{Ca}^{2+}$ into mitochondria sustain viral replication of different respiratory viruses such as RSV, MV RV [98], and SARS-CoV [97]. A recent study shows that over a two-fold increase in intracellular $\mathrm{Ca}^{2+}$ enhances the enter ability of the MERS-CoV. In the absence of $\mathrm{Ca}^{2+}$ fusion is attenuated, but not completely abrogated [96]. On the other hand, depletion of intracellular $\mathrm{Ca}^{2+}$ completely abrogates SARS-CoV host cell entry [97]. It has been shown that during viral pathogenesis deregulation of $\mathrm{Ca}^{2+}$ homeostasis alters both mitochondrial dynamics [114,115] and mitochondrial metabolic pathways to sustain cellular energy homeostasis that in turn ensure efficient virus replication and prevent mitochondrial antiviral response [116].

It has been found, recently, that human lung adenocarcinoma cell line A549, transduced with human ACE2 (hACE2), and then infected with SARS-CoV-2 show perturbations in different pathways including down regulation of genes in the mitochondrial and electron transport chain processes. Similar alterations are observed in infected human nasopharyngeal samples, used as control [93]. When we exposed A549 cells treated with nicotine to SARS-CoV-2 we found a very high virus replication without transduction of ACE2 in these cells, thus nicotine was able to increases both mRNA and protein for ACE2 allowing the entry of the virus in a big amount [47]. 
EMT is a process where epithelial cells, including those lining the lung mucosa, lose their polarity and adhesion. Thus, EMT provides migratory and invasive properties to cells. EMT develops in different pathologies including viral infections. Vimentin is one player involved into EMT. Vimentin, expressed mainly in cells of mesenchymal origin, acts together with other cytoskeletal components modulating cell migration, adhesion and division [117-120]. Additionally, Vimentin plays important roles during viral infection and replication cycles [121]. It has been reported an important role for Vimentin in SARS-CoV virus entry through interaction with its S protein [105] in the SARS-CoV-permissive cell line Vero E6 (African green monkey kidney epithelial cells). In these cells the expression of Vimentin is up-regulated after virus interaction and enhances its delivery to ACE2. Although SARS-CoV-2 is $\sim 82 \%$ identical to human SARS-CoV and $\sim 50 \%$ to MERS-CoV [122], SARS-CoV-2 shows unique features, thus the above results remain to be confirmed in human cells. However, a recently interaction map that includes all proteins of SARS-CoV-2 identified a potential interaction between several viral proteins, including $S$ protein and Vimentin [123]. In light of the above considerations, it has been speculated that drugs able to decrease the expression of Vimentin may be used for the treatment of patients with COVID-19 [120]. On the other hand, drugs that increase Vimentin expression such as nicotine may be considered extremely dangerous by increasing SARS-CoV-2 infection ability. Bioinformatics analysis shows that VEGF and FN interact with ACE2, the mRNA and protein of these molecules are more expressed in lung epithelial cells and also after SARS-CoV-2 infection [103]. Not all SARS-CoV-2 infections evolve into severe COVID-19. Looking at the different steps of SARS-CoV-2 infection ahead the lung injury (first hit), the severity of the disease is determined by the host response [124]. Indeed, the lung infection, in some patients, leads to increased expression of VEGF [125]. VEGF is a key stimulator of angiogenesis. Angiogenesis, or better neo-angiogenesis, is a physiological and well-regulated process where new blood vessels are formed from pre-existing vessels [126]. Deregulated angiogenesis is observed in pathological situations (i.e., cancer). Viruses, such as $\mathrm{CMV}$ or $\mathrm{HCV}$, may regulate angiogenesis directly or indirectly, activating vessels through endothelial cell tropism and/or producing chemokines and/or growth factors (i.e., VEGF) creating a pro-angiogenic microenvironment [108]. Morphologic and molecular features of lungs, obtained at autopsy from patients who died from SARS-CoV-2 infection show the presence of IA as well as of conventional SA [107]. IA, also called splitting angiogenesis or non-sprouting angiogenesis, is currently considered as an important alternative and complementary form of SA characterized by the presence of the so-called intraluminal tissue pillars formed by an invagination of the capillary walls into the vascular lumen [127]. Nicotine activates not only MAPK, EGFR, and VEGF pathways, but also Rb-E2F and JAK-STAT signaling pathways and its target genes [83,128,129]. Specifically, STAT3 up-regulation is $\alpha 7-\mathrm{nAChR}$ dependent. JAK-STAT is activated via EGF and VEGF [83]. Infection by SARS-CoV-2 delivers into cells NSP1 and ORF6, which efficiently inhibit STAT1 function that in turn increases STAT3 activity. The aberrant transcription in the direction of STAT3 may lead to the catastrophic cascades specific for COVID-19 patho-physiologies such as rapid coagulopathy/thrombosis, proinflammatory conditions, profibrotic status, and $\mathrm{T}$ cell lymphopenia in infected patients (reviewed in [130]).

All the observations reported by our experiments, in agreement with most literature, (Table 2) imply a strong involvement of nicotine in SARS-CoV-2 infection. In this context it is important to remind that secreted human SLURP-1 works as an auto/paracrine regulator of physiological processes indeed inhibits selectively ACh-evoked current through the $\alpha 7$ $\mathrm{nAChR}$ and suppresses the nicotine-induced up-regulation of the $\alpha 7-\mathrm{nAChR}$ expression and in turn the down-stream pathways. Interestingly, inhibitory analysis revealed that besides $\alpha 7-n A C h R$, the antiproliferative effect of SLURP-1 in transfected A549 cells is mediated by EGFR and $\beta$-arrestin $[128,129]$. SLURP-1 shares structural homology with three-finger snakes $\alpha$-neurotoxins [128,129]. Thus, SLURP-1 may protect against SARS-CoV-2.

Nevertheless, some authors believe that nicotine may protect against SARS-CoV$2[47,48,71,131]$. The fundamental hypothesis behind this statement is that nicotine reduces inflammation through its interaction with the $\mathrm{nAChR}$ and that nicotine itself interacts with 
SARS-CoV-2 inhibiting virus attachment to ACE2 $[65,67,132]$. However, the overwhelming evidences showing that nicotine potentiates cardiopulmonary diseases and may enhance viral infection make unlikely a possible therapeutic benefit in COVID-19 due to nicotine, and rather push to strengthen policies against tobacco smoking also in view of a possible SARS-CoV-2 infection.

\section{Materials and Methods}

\subsection{Cells and Treatment}

Human Bronchial Epithelial Cells (HBEpC) were obtained from Cell Applications Inc. (www.cellapplications.com/product no. 502K-05a) and cultured in complete Bronchial/ Tracheal Epithelial Cell Growth Medium (www.cellapplications.com/product) as described previously [35]. si-mRNA- $\alpha 7-\mathrm{HBEpC}$ were obtained as described previously [35]. A total of $7.5 \times 10^{4}$ cells $/ \mathrm{cm}^{2}$ semi-confluent cells were treated (a) for $1 \mathrm{~h}$ or $48 \mathrm{~h}$ with zero or $1.0 \times 10^{-7} \mathrm{M}$ nicotine (Sigma-Aldrich, Milan, Italy) dissolved in saline in complete medium; (b) treated continuously with nicotine for additional passages, 1 passage every $48 \mathrm{~h}$ for a total of 16 or 24 passages.

\subsection{Western Blot Detection}

Cells were lysed using complete lysis buffer (Roche, Monza, Italy, www.roche.it) plus protease inhibitor cocktail (PIC, Complete-M, Roche). The protein concentration was determined using the BCA protein assay (Roche). After mixing with Laemmli's buffer, samples were subjected to SDS-PAGE and Western blotting. For immunodetection, the following antibodies were used: anti-p53 (DO-1): sc-126, anti-Vimentin(V9): sc-6260, anti-Fibronectin (EP5): sc-8422, anti-E-cadherin (G-10): sc-8426, anti-Ki67 (Ki-67): sc-23900, ACE2(E-11): sc-390851 and $\alpha 4-n A C h R$ (A-6): sc-74519 (Santa Cruz Biotechnology, Inc, Dallas, TX, USA), anti- $\beta$-actin catalog number: A3853 (Sigma-Aldrich Italia). Horseradish peroxidase-labeled anti-mouse or anti-rabbit secondary antibodies catalog: 711-035-152 (Jackson, Cambridge, UK) and an enhanced chemiluminescence kit (Western blot detection reagent, GE Healthcare UK Limited, Amersham, UK) were used for the detection of recognized proteins. Primary antibody was diluted 1:1000 and secondary 1:10,000. Densitometric analysis for quantification of the relative level of protein expression was performed using Amersham Image Quant800 (EG Healthcare) with software ImageQuant TL 7.0 ${ }^{\circledR}$.

\subsection{Evaluation of p53/phosphor-p53, p38/phospo-p38, Calcium, ATP, EGFR/p-EGFR, and VEGF}

PathScan ${ }^{\circledR}$ apoptosis multi-target sandwich ELISA kit (Cell signaling technology) was used to detect p53 and phospho-p53 (pP53). Calcium detection assay kit (colorimetric) ab102505 was purchased from Abcam (Biotech, Life sciences, Cambridge, UK). ATP colorimetric assay kit (k354-100) was purchased from BioVision (Milpitas, CA, USA). Human EGFR (pY1068) ELISA kit (KHR9081) and Human EGFR (Full length) ELISA kit (KO-IR9061) were purchased from Invitrogen (Thermo-Fisher, Waltham, MA, USA). Human VEGF QuantiGlo ELISA Kit (QVE00B) was purchased from R\&D Systems, Inc. (Minneapolis, MN, USA). STAR phospho-p38 $\alpha$ (Thr180/Tyr182) ELISA Kit: 17-488 was purchased from Merck-Sigma Aldrich (Milan, Italy); p38 MAPK (Total) Human ELISA Kit (KHO0061) were purchased from Invitrogen (Thermo-Fisher, Waltham, MA, USA). All experiments were performed according to the manufacture's protocol.

\subsection{Cell Migration}

CytoSelect ${ }^{\circledR}$ 24-Well Cell Migration Assay ( $8 \mu \mathrm{m}$, Fluorometric format) was obtained from Cell Biolabs (catalog number CBA-101-C (San Diego, CA, USA)) and experiments were performed according to the manufacture's protocol. 


\subsection{Cellular Senescence}

The 96-Well Cellular Senescence Assay Kit (SA- $\beta$-Gal Activity, Fluorometric Format) was obtained from Cell Biolabs (catalog number CBA-231 (San Diego, CA, USA)) and experiments were performed according to the manufacture's protocol.

\subsection{Cell Transformation}

CytoSelect $^{\mathrm{TM}}$ 96-well cell transformation Assay (CBA-140) was purchased from Cell Biolabs Inc. (San Diego, CA, USA) and experiments were performed according to the manufacture's protocol.

\subsection{Statistical Analysis}

Data were managed and analyzed using GraphPad Prism 8.1 ${ }^{\circledR}$ (GraphPad Software Inc., La Jolla, CA, USA); two tails paired $t$-test or one-way ANOVA with multiplecomparison and post hoc test with Bonferroni correction were used to evaluate statistical significance. Data were described as mean \pm SD (standard deviation). A $p$-value of $<0.05$ was considered as statistically significant. Each experiment was performed at least two times in separate experiments done at least in triplicate.

\section{Conclusions}

Based on our results and on evidence showing that nicotine potentiates viral infection it is likely that nicotine is involved in SARS-CoV-2 infection and severity

Supplementary Materials: The following are available online: Supplemental data and raw data of Western blot.

Author Contributions: Conceptualization, P.R.; L.L., D.M., and F.M.; methodology, L.L., C.D.D.; formal analysis, L.L., C.D.D., and C.M.; investigation, P.R., L.L., and F.M.; resources, M.F., C.T.; data curation, L.L., C.D.D., and C.M.; writing-original draft preparation, P.R., D.M.; writingreview and editing, D.M., C.T., S.B., and F.M.; supervision, F.M., S.B.; project administration, C.T.; funding acquisition, M.F. All authors have read and agreed to the published version of the manuscript.

Funding: This research is supported by funds from Italian Health Ministry (Ricerca Corrente to PR) 2020, Roma Italy.

Data Availability Statement: The data presented in this study are available on request from the corresponding author. The western blotting images presented in this study are available in supplementary material.

Acknowledgments: We thank Enrico Garaci (Department of Human Sciences and Quality of Life Promotion San Raffaele University, Rome, Italy) for the helpful comments and suggestions.

Conflicts of Interest: The authors declare no conflict of interest.

Sample Availability: Samples of the compounds (nicotine) are available from the authors.

$\begin{array}{ll}\text { Abbreviations } & \\ \text { A549 human lung carcinoma cells transfected with human ACE2 } & \text { ACE2-A549 } \\ \text { Acetylcholine } & \text { ACh } \\ \text { Acetylcholinesterase } & \text { AChE } \\ \text { Angiotensin-converting enzyme 2 } & \text { ACE2 } \\ \text { Butyrylcholinesterase } & \text { BuChE } \\ \text { Choline acetyltransferase } & \text { ChAT } \\ \text { Cholinergic Receptor Nicotinic Alpha 7 Subunit gene } & \text { CHRNA7 } \\ \text { Cholinergic system } & \text { CS } \\ \text { Cyclic adenosine monophosphate } & \text { cAMP } \\ \text { Cytomegalovirus } & \text { CMV } \\ \text { Epithelial cell adhesion molecule } & \text { EpCAM } \\ \text { Epithelial-mesenchymal transition } & \text { EMT } \\ \text { Fibronectin } & \text { FN }\end{array}$


Hepatitis $C$ virus

Human bronchial epithelial cells

Human Coronavirus NL63

Human immunodeficiency virus

Influenza virus

International Union of Pure and Applied Chemistry

Intussusceptive angiogenesis

Ly-6/uPAR-related protein 1

Measles virus

Middle East respiratory syndrome Coronavirus

Muscarinic receptor

Nicotinic receptor

Open Reading Frame 6

Primary Human normal bronchial epithelial

Renin-Angiotensin System

Respiratory syncytial virus

Rhinovirus

Secondary metabolite(s)

Senescence-associated $\beta$-galactosidase

Severe Acute Respiratory Syndrome Corona Virus-2

Sprouting angiogenesis

Transmembrane protease, serine 2

Vascular endothelial growth factor

Vesicular acetylcholine transporter
$\mathrm{HCV}$

HBEpC

HCoV-NL63

HIV

IAV

IUPAC

IA

SLURP-1

MV

MERS-CoV

mAChR

nAChR

ORF6

NHBE

RAS

RSV

RV

SM

SA- $\beta-$ Gal

SARS-CoV-2

SA

TMPRSS2

VEGF

VAChT

\section{References}

1. Properties of Nicotine. Available online: http:/ / www.chm.bris.ac.uk/motm/nicotine/E-propriete.html (accessed on 18 December 2020).

2. Yildiz, D. Nicotine, its metabolism and an overview of its biological effects. Toxicon 2004, 43, 619-632. [CrossRef] [PubMed]

3. Russo, P.; Nastrucci, C.; Alzetta, G.; Szalai, C. Tobacco habit: Historical, cultural, neurobiological, and genetic features of people's relationship with an addictive drug. Perspect. Biol. Med. 2011, 54, 557-577. [CrossRef] [PubMed]

4. Steppuhn, A.; Gase, K.; Krock, B.; Halitschke, R.; Baldwin, I.T. Nicotine's defensive function in nature. PLoS Biol. 2004,2 , E217. [CrossRef] [PubMed]

5. Kumar, P.; Pandit, S.S.; Steppuhn, A.; Baldwin, I.T. Natural history-driven, plant-mediated RNAi-based study reveals CYP6B46's role in a nicotine-mediated antipredator herbivore defense. Proc. Natl. Acad. Sci. USA 2014, 111, 1245-1252. [CrossRef] [PubMed]

6. Moghbel, N.; Ryu, B.; Ratsch, A.; Steadman, K.J. Nicotine alkaloid levels, and nicotine to nornicotine conversion, in Australian Nicotiana species used as chewing tobacco. Heliyon 2017, 3, e00469. [CrossRef] [PubMed]

7. Mayer, B. How much nicotine kills a human? Tracing back the generally accepted lethal dose to dubious self-experiments in the nineteenth century. Arch. Toxicol. 2014, 88, 5-7. [CrossRef]

8. Alkam, T.; Nabeshima, T. Molecular mechanisms for nicotine intoxication. Neurochem. Int. 2019, 125, 117-126. [CrossRef]

9. Matta, S.G.; Balfour, D.J.; Benowitz, N.L.; Boyd, R.T.; Buccafusco, J.J.; Caggiula, A.R.; Craig, C.R.; Collins, A.C.; Damaj, M.I.; Donny, E.C.; et al. Guidelines on nicotine dose selection for in vivo research. Psychopharmacology 2007, 190, 269-319. [CrossRef]

10. Changeux, J.P. The nicotinic acetylcholine receptor: A typical 'allosteric machine'. Philos. Trans. R. Soc. Lond B Biol. Sci. 2018, 373. [CrossRef]

11. Zoli, M.; Pucci, S.; Vilella, A.; Gotti, C. Neuronal and Extraneuronal Nicotinic Acetylcholine Receptors. Curr. Neuropharmacol. 2018, 16, 338-349. [CrossRef]

12. Cardinale, A.; Nastrucci, C.; Cesario, A.; Russo, P. Nicotine: Specific role in angiogenesis, proliferation and apoptosis. Crit. Rev. Toxicol. 2012, 42, 68-89. [CrossRef] [PubMed]

13. Dwoskin, L.P.; Smith, A.M.; Wooters, T.E.; Zhang, Z.; Crooks, P.A.; Bardo, M.T. Nicotinic receptor-based therapeutics and candidates for smoking cessation. Biochem. Pharmacol. 2009, 78, 732-743. [CrossRef] [PubMed]

14. Daly, J.W. Nicotinic agonists, antagonists, and modulators from natural sources. Cell Mol. Neurobiol. 2005, 25, 513-552. [CrossRef] [PubMed]

15. Xing, H.; Andrud, K.W.; Soti, F.; Rouchaud, A.; Jahn, S.C.; Lu, Z.; Cho, Y.H.; Habibi, S.; Corsino, P.; Slavov, S.; et al. A Methyl Scan of the Pyrrolidinium Ring of Nicotine Reveals Significant Differences in its Interactions with alpha7 and alpha4beta2 Nicotinic Acetylcholine Receptors. Mol. Pharmacol. 2020, 98, 168-180. [CrossRef] [PubMed]

16. Picciotto, M.R.; Kenny, P.J. Mechanisms of Nicotine Addiction. Cold Spring Harb. Perspect. Med. 2020. [CrossRef] [PubMed]

17. Paleari, L.; Grozio, A.; Cesario, A.; Russo, P. The cholinergic system and cancer. Semin. Cancer Biol. 2008, 18, 211-217. [CrossRef] [PubMed] 
18. Sheppard, B.J.; Williams, M.; Plummer, H.K.; Schuller, H.M. Activation of voltage-operated Ca ${ }^{2+}$-channels in human small cell lung carcinoma by the tobacco-specific nitrosamine 4-(methylnitrosamino)-1-(3-pyridyl)-1-butanone. Int. J. Oncol. 2000, 16, 513-521. [CrossRef]

19. Schuller, H.M. Is cancer triggered by altered signalling of nicotinic acetylcholine receptors? Nat. Rev. Cancer 2009, 9, 195-205. [CrossRef]

20. Hurst, R.; Rollema, H.; Bertrand, D. Nicotinic acetylcholine receptors: From basic science to therapeutics. Pharmacol. Ther. 2013, 137, 22-54. [CrossRef]

21. Grando, S.A.; Kawashima, K.; Wessler, I. A historic perspective on the current progress in elucidation of the biologic significance of non-neuronal acetylcholine. Int. Immunopharmacol. 2020, 81, 106289. [CrossRef]

22. Cox, M.A.; Bassi, C.; Saunders, M.E.; Nechanitzky, R.; Morgado-Palacin, I.; Zheng, C.; Mak, T.W. Beyond neurotransmission: Acetylcholine in immunity and inflammation. J. Intern. Med. 2020, 287, 120-133. [CrossRef] [PubMed]

23. Wessler, I.K.; Kirkpatrick, C.J. Activation of Muscarinic Receptors by Non-neuronal Acetylcholine. In Muscarinic Receptors; Fryer, A.D., Christopoulos, A., Nathanson, N.M., Eds.; Springer: Berlin/Heidelberg, Germany, 2012; pp. $469-491$.

24. Wessler, I.; Kilbinger, H.; Bittinger, F.; Kirkpatrick, C.J. The biological role of non-neuronal acetylcholine in plants and humans. Jpn. J. Pharmacol. 2001, 85, 2-10. [CrossRef] [PubMed]

25. Wessler, I.K.; Kirkpatrick, C.J. Non-neuronal acetylcholine involved in reproduction in mammals and honeybees. J. Neurochem. 2017, 142, 144-150. [CrossRef] [PubMed]

26. Wessler, I.; Kilbinger, H.; Bittinger, F.; Unger, R.; Kirkpatrick, C.J. The non-neuronal cholinergic system in humans: Expression, function and pathophysiology. Life Sci. 2003, 72, 2055-2061. [CrossRef]

27. Aluigi, M.G.; Diaspro, A.; Ramoino, P.; Russo, P.; Falugi, C. The sea urchin, Paracentrotus lividus, as a model to investigate the onset of molecules immunologically related to the alpha-7 subunit of nicotinic receptors during embryonic and larval development. Curr. Drug Targets 2012, 13, 587-593. [CrossRef]

28. Wang, H.; Yu, M.; Ochani, M.; Amella, C.A.; Tanovic, M.; Susarla, S.; Li, J.H.; Wang, H.; Yang, H.; Ulloa, L.; et al. Nicotinic acetylcholine receptor alpha7 subunit is an essential regulator of inflammation. Nature 2003, 421, 384-388. [CrossRef]

29. Paleari, L.; Cesario, A.; Fini, M.; Russo, P. alpha7-Nicotinic receptor antagonists at the beginning of a clinical era for NSCLC and Mesothelioma? Drug Discov. Today 2009, 14, 822-836. [CrossRef]

30. Maouche, K.; Medjber, K.; Zahm, J.M.; Delavoie, F.; Terryn, C.; Coraux, C.; Pons, S.; Cloez-Tayarani, I.; Maskos, U.; Birembaut, P.; et al. Contribution of alpha7 nicotinic receptor to airway epithelium dysfunction under nicotine exposure. Proc. Natl. Acad. Sci. USA 2013, 110, 4099-4104. [CrossRef]

31. Krais, A.M.; Hautefeuille, A.H.; Cros, M.P.; Krutovskikh, V.; Tournier, J.M.; Birembaut, P.; Thepot, A.; Paliwal, A.; Herceg, Z.; Boffetta, P.; et al. CHRNA5 as negative regulator of nicotine signaling in normal and cancer bronchial cells: Effects on motility, migration and p63 expression. Carcinogenesis 2011, 32, 1388-1395. [CrossRef]

32. Sartelet, H.; Maouche, K.; Totobenazara, J.L.; Petit, J.; Burlet, H.; Monteau, M.; Tournier, J.M.; Birembaut, P. Expression of nicotinic receptors in normal and tumoral pulmonary neuroendocrine cells (PNEC). Pathol. Res. Pract. 2008, 204, 891-898. [CrossRef]

33. Lam, D.C.L.; Luo, S.Y.; Fu, K.H.; Lui, M.M.S.; Chan, K.H.; Wistuba, I.I.; Gao, B.; Tsao, S.W.; Ip, M.S.M.; Minna, J.D. Nicotinic acetylcholine receptor expression in human airway correlates with lung function. Am. J. Physiol. Lung Cell Mol. Physiol. 2016, 310, L232-L239. [CrossRef] [PubMed]

34. Li, Q.; Zhou, X.; Kolosov, V.P.; Perelman, J.M. The expression and pharmacological characterization of nicotinic acetylcholine receptor subunits in HBE16 airway epithelial cells. Cell Biochem. Biophys. 2012, 62, 421-431. [CrossRef] [PubMed]

35. Russo, P.; Bonassi, S.; Giacconi, R.; Malavolta, M.; Tomino, C.; Maggi, F. COVID-19 and smoking: Is nicotine the hidden link? Eur. Respir. J. 2020, 55. [CrossRef] [PubMed]

36. Leung, J.M.; Yang, C.X.; Sin, D.D. COVID-19 and nicotine as a mediator of ACE-2. Eur. Respir. J. 2020, 55. [CrossRef] [PubMed]

37. Olds, J.L.; Kabbani, N. Is nicotine exposure linked to cardiopulmonary vulnerability to COVID-19 in the general population? FEBS J. 2020. [CrossRef] [PubMed]

38. Yan, R.; Zhang, Y.; Li, Y.; Xia, L.; Guo, Y.; Zhou, Q. Structural basis for the recognition of SARS-CoV-2 by full-length human ACE2. Science 2020, 367, 1444-1448. [CrossRef]

39. Zhou, P.; Yang, X.L.; Wang, X.G.; Hu, B.; Zhang, L.; Zhang, W.; Si, H.R.; Zhu, Y.; Li, B.; Huang, C.L.; et al. A pneumonia outbreak associated with a new coronavirus of probable bat origin. Nature 2020, 579, 270-273. [CrossRef]

40. Costa, L.B.; Perez, L.G.; Palmeira, V.A.; Macedo, E.C.T.; Ribeiro, V.T.; Lanza, K.; Simoes, E.S.A.C. Insights on SARS-CoV-2 Molecular Interactions with the Renin-Angiotensin System. Front. Cell Dev. Biol. 2020, 8, 559841. [CrossRef]

41. van de Veerdonk, F.; Netea, M.G.; van Deuren, M.; van der Meer, J.W.M.; de Mast, Q.; Bruggemann, R.J.; van der Hoeven, H. Kinins and Cytokines in COVID-19: A Comprehensive Pathophysiological Approach. 2020. 2020040023. Available online: 10.20944/ preprints202004.0023.v1. (accessed on 18 December 2020).

42. Hou, Y.J.; Okuda, K.; Edwards, C.E.; Martinez, D.R.; Asakura, T.; Dinnon, K.H., 3rd; Kato, T.; Lee, R.E.; Yount, B.L.; Mascenik, T.M.; et al. SARS-CoV-2 Reverse Genetics Reveals a Variable Infection Gradient in the Respiratory Tract. Cell 2020, 182, 429-446e14. [CrossRef]

43. Milne, S.; Yang, C.X.; Timens, W.; Bosse, Y.; Sin, D.D. SARS-CoV-2 receptor ACE2 gene expression and RAAS inhibitors. Lancet Respir. Med. 2020, 8, e50-e51. [CrossRef]

44. Lukassen, S.; Chua, R.L.; Trefzer, T.; Kahn, N.C.; Schneider, M.A.; Muley, T.; Winter, H.; Meister, M.; Veith, C.; Boots, A.W.; et al. SARS-CoV-2 receptor ACE2 and TMPRSS2 are primarily expressed in bronchial transient secretory cells. EMBO J. 2020, 39, e105114. [CrossRef] [PubMed] 
45. Cai, G.; Bosse, Y.; Xiao, F.; Kheradmand, F.; Amos, C.I. Tobacco Smoking Increases the Lung Gene Expression of ACE2, the Receptor of SARS-CoV-2. Am. J. Respir. Crit. Care Med. 2020, 201, 1557-1559. [CrossRef] [PubMed]

46. Leung, J.M.; Niikura, M.; Yang, C.W.T.; Sin, D.D. COVID-19 and COPD. Eur. Respir. J. 2020, 56. [CrossRef] [PubMed]

47. Russo, P. Expert view smoking, nicotine, and COVID-19 myths and facts. Available online: https:/ / www.sciencemediacentre. org/expert-reaction-to-questions-about-smoking-and-covid-19/ (accessed on 18 December 2020).

48. Lupacchini, L.T.C.; Russo, P. COVID-19 infection, and Nicotine. Systematic revision of the literature. Tabaccologia $2020,3,8$.

49. Farsalinos, K.; Barbouni, A.; Niaura, R. Systematic review of the prevalence of current smoking among hospitalized COVID-19 patients in China: Could nicotine be a therapeutic option? Intern. Emerg. Med. 2020, 15, 845-852. [CrossRef]

50. Giannouchos, T.V.; Sussman, R.A.; Mier, J.M.; Poulas, K.; Farsalinos, K. Characteristics and risk factors for COVID-19 diagnosis and adverse outcomes in Mexico: An analysis of 89,756 laboratory-confirmed COVID-19 cases. Eur. Respir. J. 2020. [CrossRef]

51. Israel, A.; Feldhamer, I.; Lahad, A.; Levin-Zamir, D.; Lavie, G. Smoking and the risk of COVID-19 in a large observational population study. medRxiv 2020. [CrossRef]

52. Miyara, M.; Tubach, F.; Martinez, V.; Morelot-Panzini, C.; Pernet, J.; Haroche, J.; Lebbah, S.; Morawiec, E.; Gorochov, G.; Caumes, E.; et al. Low rate of daily smokers in patients with symptomatic COVID-19. medRxiv 2020. [CrossRef]

53. Zureik, M.; Baricault, B.; Vabre, C.; Semenzato, L.; Drouin, J.; cuenot, F.; penso, L.; Herlemont, P.; Sbidian, E.; Weill, A.; et al. Nicotine-replacement therapy, as a surrogate of smoking, and the risk of hospitalization with Covid-19 and all-cause mortality: A nationwide, observational cohort study in France. medRxiv 2020. [CrossRef]

54. Tattan-Birch, H.; Perski, O.; Jackson, S.; Shahab, L.; West, R.; Brown, J. COVID-19, smoking, vaping and quitting: A representative population survey in England. Addiction 2020. [CrossRef]

55. Vardavas, C.I.; Nikitara, K. COVID-19 and smoking: A systematic review of the evidence. Tob. Induc. Dis. 2020, 18, 20. [CrossRef] [PubMed]

56. Berlin, I.; Thomas, D.; Le Faou, A.L.; Cornuz, J. COVID-19 and Smoking. Nicotine Tob. Res. 2020, 22, 1650-1652. [CrossRef] [PubMed]

57. Zhao, Q.; Meng, M.; Kumar, R.; Wu, Y.; Huang, J.; Lian, N.; Deng, Y.; Lin, S. The impact of COPD and smoking history on the severity of COVID-19: A systemic review and meta-analysis. J. Med. Virol. 2020, 92, 1915-1921. [CrossRef] [PubMed]

58. Van Zyl-Smit, R.N.; Richards, G.; Leone, F.T. Tobacco smoking and COVID-19 infection. Lancet Respir. Med. 2020, 8, 664-665. [CrossRef]

59. Alqahtani, J.S.; Oyelade, T.; Aldhahir, A.M.; Alghamdi, S.M.; Almehmadi, M.; Alqahtani, A.S.; Quaderi, S.; Mandal, S.; Hurst, J.R. Prevalence, Severity and Mortality associated with COPD and Smoking in patients with COVID-19: A Rapid Systematic Review and Meta-Analysis. PLoS ONE 2020, 15, e0233147. [CrossRef]

60. Tsigaris, P.; Teixeira da Silva, J.A. Smoking Prevalence and COVID-19 in Europe. Nicotine Tob. Res. 2020, 22, 1646-1649. [CrossRef]

61. Cattaruzza, M.S.; Zaga, V.; Gallus, S.; D'Argenio, P.; Gorini, G. Tobacco smoking and COVID-19 pandemic: Old and new issues. A summary of the evidence from the scientific literature. Acta Biomed. 2020, 91, 106-112. [CrossRef]

62. Cattaruzza, M.S.; Gorini, G.; Bosetti, C.; Boffi, R.; Lugo, A.; Veronese, C.; Carreras, G.; Santucci, C.; Stival, C.; Pacifici, R.; et al. Covid-19 and the role of smoking: The protocol of the multicentric prospective study COSMO-IT (COvid19 and SMOking in ITaly). Acta Bio-Medica: Atenei Parm. 2020, 91, e2020062. [CrossRef]

63. Gaiha, S.M.; Cheng, J.; Halpern-Felsher, B. Association Between Youth Smoking, Electronic Cigarette Use, and COVID-19. J. Adolesc Health 2020, 67, 519-523. [CrossRef]

64. Wang, Q.; Sundar, I.K.; Li, D.; Lucas, J.H.; Muthumalage, T.; McDonough, S.R.; Rahman, I. E-cigarette-induced pulmonary inflammation and dysregulated repair are mediated by nAChR alpha7 receptor: Role of nAChR alpha7 in SARS-CoV-2 Covid-19 ACE2 receptor regulation. Respir. Res. 2020, 21, 154. [CrossRef]

65. Changeux, J.P.; Amoura, Z.; Rey, F.A.; Miyara, M. A nicotinic hypothesis for Covid-19 with preventive and therapeutic implications. C R Biol. 2020, 343, 33-39.

66. Hanahan, D.; Weinberg, R.A. Hallmarks of cancer: The next generation. Cell 2011, 144, 646-674. [CrossRef]

67. Farsalinos, K.; Eliopoulos, E.; Leonidas, D.D.; Papadopoulos, G.E.; Tzartos, S.; Poulas, K. Nicotinic Cholinergic System and COVID-19: In Silico Identification of an Interaction between SARS-CoV-2 and Nicotinic Receptors with Potential Therapeutic Targeting Implications. Int. J. Mol. Sci. 2020, 21, 5807. [CrossRef]

68. Oliveira, A.S.F.; Ibarra, A.A.; Bermudez, I.; Casalino, L.; Gaieb, Z.; Shoemark, D.K.; Gallagher, T.; Sessions, R.B.; Amaro, R.E.; Mulholland, A.J. Simulations support the interaction of the SARS-CoV-2 spike protein with nicotinic acetylcholine receptors and suggest subtype specificity. BioRxiv 2020. [CrossRef]

69. Hasanagic, S.; Serdarevic, F. Potential role of memantine in the prevention and treatment of COVID-19: Its antagonism of nicotinic acetylcholine receptors and beyond. Eur. Respir. J. 2020, 56. [CrossRef] [PubMed]

70. Capo-Velez, C.M.; Delgado-Velez, M.; Baez-Pagan, C.A.; Lasalde-Dominicci, J.A. Nicotinic Acetylcholine Receptors in HIV: Possible Roles During HAND and Inflammation. Cell Mol. Neurobiol. 2018, 38, 1335-1348. [CrossRef] [PubMed]

71. Sifat, A.E.; Nozohouri, S.; Villalba, H.; Vaidya, B.; Abbruscato, T.J. The Role of Smoking and Nicotine in the Transmission and Pathogenesis of COVID-19. J. Pharmacol. Exp. Ther. 2020, 375, 498-509. [CrossRef]

72. Li, W.; Sui, J.; Huang, I.C.; Kuhn, J.H.; Radoshitzky, S.R.; Marasco, W.A.; Choe, H.; Farzan, M. The S proteins of human coronavirus NL63 and severe acute respiratory syndrome coronavirus bind overlapping regions of ACE2. Virology 2007, 367, 367-374. [CrossRef]

73. Li, G.; He, X.; Zhang, L.; Ran, Q.; Wang, J.; Xiong, A.; Wu, D.; Chen, F.; Sun, J.; Chang, C. Assessing ACE2 expression patterns in lung tissues in the pathogenesis of COVID-19. J. Autoimmun. 2020, 112, 102463. [CrossRef] 
74. Bouhaddou, M.; Memon, D.; Meyer, B.; White, K.M.; Rezelj, V.V.; Correa Marrero, M.; Polacco, B.J.; Melnyk, J.E.; Ulferts, S.; Kaake, R.M.; et al. The Global Phosphorylation Landscape of SARS-CoV-2 Infection. Cell 2020, 182, 685-712e19. [CrossRef]

75. Ma, Q.; Pan, W.; Li, R.; Liu, B.; Li, C.; Xie, Y.; Wang, Z.; Zhao, J.; Jiang, H.; Huang, J.; et al. Liu Shen capsule shows antiviral and antiinflammatory abilities against novel coronavirus SARS-CoV-2 via suppression of NF-kappaB signaling pathway. Pharmacol. Res. 2020, 158, 104850. [CrossRef] [PubMed]

76. Kopecky-Bromberg, S.A.; Martinez-Sobrido, L.; Palese, P. 7a protein of severe acute respiratory syndrome coronavirus inhibits cellular protein synthesis and activates p38 mitogen-activated protein kinase. J. Virol. 2006, 80, 785-793. [CrossRef] [PubMed]

77. Catassi, A.; Servent, D.; Paleari, L.; Cesario, A.; Russo, P. Multiple roles of nicotine on cell proliferation and inhibition of apoptosis: Implications on lung carcinogenesis. Mutat. Res. 2008, 659, 221-231. [CrossRef] [PubMed]

78. Bojkova, D.; Klann, K.; Koch, B.; Widera, M.; Krause, D.; Ciesek, S.; Cinatl, J.; Munch, C. Proteomics of SARS-CoV-2-infected host cells reveals therapy targets. Nature 2020, 583, 469-472. [CrossRef] [PubMed]

79. Pruijssers, A.J.; Denison, M.R. Nucleoside analogues for the treatment of coronavirus infections. Curr. Opin. Virol. 2019, 35, 57-62. [CrossRef] [PubMed]

80. Thoms, M.; Buschauer, R.; Ameismeier, M.; Koepke, L.; Denk, T.; Hirschenberger, M.; Kratzat, H.; Hayn, M.; Mackens-Kiani, T.; Cheng, J.; et al. Structural basis for translational shutdown and immune evasion by the Nsp1 protein of SARS-CoV-2. Science 2020, 369, 1249-1255. [CrossRef]

81. Stewart, C.A.; Gay, C.M.; Ramkumar, K.; Cargill, K.R.; Cardnell, R.J.; Nilsson, M.B.; Heeke, S.; Park, E.M.; Kundu, S.T.; Diao, L.; et al. SARS-CoV-2 infection induces EMT-like molecular changes, including ZEB1-mediated repression of the viral receptor ACE2, in lung cancer models. BioRxiv 2020. [CrossRef]

82. Carlisle, D.L.; Liu, X.; Hopkins, T.M.; Swick, M.C.; Dhir, R.; Siegfried, J.M. Nicotine activates cell-signaling pathways through muscle-type and neuronal nicotinic acetylcholine receptors in non-small cell lung cancer cells. Pulm. Pharmacol. Ther. 2007, 20, 629-641. [CrossRef]

83. Schaal, C.; Chellappan, S.P. Nicotine-mediated cell proliferation and tumor progression in smoking-related cancers. Mol. Cancer Res. 2014, 12, 14-23. [CrossRef]

84. Sacar Demirci, M.D.; Adan, A. Computational analysis of microRNA-mediated interactions in SARS-CoV-2 infection. Peer J. 2020, 8, e9369. [CrossRef]

85. Turk, C.; Turk, S.; Temirci, E.S.; Malkan, U.Y.; Haznedaroglu, I.C. In vitro analysis of the renin-angiotensin system and inflammatory gene transcripts in human bronchial epithelial cells after infection with severe acute respiratory syndrome coronavirus. J. Renin. Angiotensin. Aldosterone Syst. 2020, 21. [CrossRef] [PubMed]

86. Puliyappadamba, V.T.; Cheriyan, V.T.; Thulasidasan, A.K.; Bava, S.V.; Vinod, B.S.; Prabhu, P.R.; Varghese, R.; Bevin, A.; Venugopal, S.; Anto, R.J. Nicotine-induced survival signaling in lung cancer cells is dependent on their p53 status while its down-regulation by curcumin is independent. Mol. Cancer 2010, 9, 220. [CrossRef] [PubMed]

87. Zhang, Q.; Ganapathy, S.; Avraham, H.; Nishioka, T.; Chen, C. Nicotine exposure potentiates lung tumorigenesis by perturbing cellular surveillance. Br. J. Cancer 2020, 122, 904-911. [CrossRef] [PubMed]

88. Ramaiah, M.J. mTOR inhibition and p53 activation, microRNAs: The possible therapy against pandemic COVID-19. Gene Rep. 2020, 20, 100765. [CrossRef]

89. Aloni-Grinstein, R.; Charni-Natan, M.; Solomon, H.; Rotter, V. p53 and the Viral Connection: Back into the Future (double dagger). Cancers 2018, 10, 178. [CrossRef]

90. Zhang, J.; Kamdar, O.; Le, W.; Rosen, G.D.; Upadhyay, D. Nicotine induces resistance to chemotherapy by modulating mitochondrial signaling in lung cancer. Am. J. Respir. Cell Mol. Biol 2009, 40, 135-146. [CrossRef]

91. Manevski, M.; Muthumalage, T.; Devadoss, D.; Sundar, I.K.; Wang, Q.; Singh, K.P.; Unwalla, H.J.; Chand, H.S.; Rahman, I. Cellular stress responses and dysfunctional Mitochondrial-cellular senescence, and therapeutics in chronic respiratory diseases. Redox Biol. 2020, 33, 101443. [CrossRef]

92. Malinska, D.; Wieckowski, M.R.; Michalska, B.; Drabik, K.; Prill, M.; Patalas-Krawczyk, P.; Walczak, J.; Szymanski, J.; Mathis, C.; Van der Toorn, M.; et al. Mitochondria as a possible target for nicotine action. J. Bioenerg. Biomembr. 2019, 51, 259-276. [CrossRef]

93. Singh, K.; Chen, Y.C.; Judy, J.T.; Seifuddin, F.; Tunc, I.; Pirooznia, M. Network Analysis and Transcriptome Profiling Identify Autophagic and Mitochondrial Dysfunctions in SARS-CoV-2 Infection. BioRxiv 2020. [CrossRef]

94. Wang, Y.; He, J.; Jiang, H.; Zhang, Q.; Yang, H.; Xu, X.; Zhang, C.; Xu, C.; Wang, J.; Lu, W. Nicotine enhances storeoperated calcium entry by upregulating HIF1alpha and SOCC components in nonsmall cell lung cancer cells. Oncol. Rep. 2018, 40, 2097-2104.

95. Zia, S.; Ndoye, A.; Nguyen, V.T.; Grando, S.A. Nicotine enhances expression of the alpha 3, alpha 4, alpha 5, and alpha 7 nicotinic receptors modulating calcium metabolism and regulating adhesion and motility of respiratory epithelial cells. Res. Commun. Mol. Pathol. Pharmacol. 1997, 97, 243-262. [PubMed]

96. Straus, M.R.; Tang, T.; Lai, A.L.; Flegel, A.; Bidon, M.; Freed, J.H.; Daniel, S.; Whittaker, G.R. Ca(2+) Ions Promote Fusion of Middle East Respiratory Syndrome Coronavirus with Host Cells and Increase Infectivity. J. Virol. 2020, 94. [CrossRef] [PubMed]

97. Lai, A.L.; Millet, J.K.; Daniel, S.; Freed, J.H.; Whittaker, G.R. The SARS-CoV Fusion Peptide Forms an Extended Bipartite Fusion Platform that Perturbs Membrane Order in a Calcium-Dependent Manner. J. Mol. Biol. 2017, 429, 3875-3892. [CrossRef] [PubMed]

98. Jayaseelan, V.P.; Paramasivam, A. Repurposing calcium channel blockers as antiviral drugs. J. Cell Commun. Signal 2020, 14, 467-468. [CrossRef] [PubMed] 
99. Dasgupta, P.; Rizwani, W.; Pillai, S.; Kinkade, R.; Kovacs, M.; Rastogi, S.; Banerjee, S.; Carless, M.; Kim, E.; Coppola, D.; et al. Nicotine induces cell proliferation, invasion and epithelial-mesenchymal transition in a variety of human cancer cell lines. Int. J. Cancer 2009, 124, 36-45. [CrossRef] [PubMed]

100. Zou, W.; Zou, Y.; Zhao, Z.; Li, B.; Ran, P. Nicotine-induced epithelial-mesenchymal transition via Wnt/beta-catenin signaling in human airway epithelial cells. Am. J. Physiol. Lung Cell Mol. Physiol. 2013, 304, L199-L209. [CrossRef] [PubMed]

101. Roman, J.; Ritzenthaler, J.D.; Gil-Acosta, A.; Rivera, H.N.; Roser-Page, S. Nicotine and fibronectin expression in lung fibroblasts: Implications for tobacco-related lung tissue remodeling. FASEB J. 2004, 18, 1436-1438. [CrossRef]

102. Zheng, Y.; Ritzenthaler, J.D.; Roman, J.; Han, S. Nicotine stimulates human lung cancer cell growth by inducing fibronectin expression. Am. J. Respir. Cell Mol. Biol. 2007, 37, 681-690. [CrossRef]

103. Xu, J.; Xu, X.; Jiang, L.; Dua, K.; Hansbro, P.M.; Liu, G. SARS-CoV-2 induces transcriptional signatures in human lung epithelial cells that promote lung fibrosis. Respir. Res. 2020, 21, 182. [CrossRef]

104. Zhang, C.; Yu, P.; Zhu, L.; Zhao, Q.; Lu, X.; Bo, S. Blockade of alpha7 nicotinic acetylcholine receptors inhibit nicotine-induced tumor growth and vimentin expression in non-small cell lung cancer through MEK/ERK signaling way. Oncol. Rep. 2017, 38, 3309-3318.

105. Yu, Y.T.; Chien, S.C.; Chen, I.Y.; Lai, C.T.; Tsay, Y.G.; Chang, S.C.; Chang, M.F. Surface vimentin is critical for the cell entry of SARS-CoV. J. Biomed. Sci. 2016, 23, 14. [CrossRef] [PubMed]

106. Fararjeh, A.S.; Tu, S.H.; Chen, L.C.; Cheng, T.C.; Liu, Y.R.; Chang, H.L.; Chang, H.W.; Huang, C.C.; Wang, H.R.; Hwang-Verslues, W.W.; et al. Long-term exposure to extremely low-dose of nicotine and 4-(methylnitrosamino)-1-(3-pyridyl)-1butanone $(\mathrm{NNK})$ induce non-malignant breast epithelial cell transformation through activation of the a9-nicotinic acetylcholine receptor-mediated signaling pathway. Environ. Toxicol. 2019, 34, 73-82. [PubMed]

107. Ackermann, M.; Verleden, S.E.; Kuehnel, M.; Haverich, A.; Welte, T.; Laenger, F.; Vanstapel, A.; Werlein, C.; Stark, H.; Tzankov, A.; et al. Pulmonary Vascular Endothelialitis, Thrombosis, and Angiogenesis in Covid-19. N. Engl. J. Med. 2020, 383, 120-128. [CrossRef] [PubMed]

108. Vrancken, K.; Vervaeke, P.; Balzarini, J.; Liekens, S. Viruses as key regulators of angiogenesis. Rev. Med. Virol. 2011, 21, 181-200. [CrossRef]

109. Chernyavsky, A.I.; Shchepotin, I.B.; Grando, S.A. Mechanisms of growth-promoting and tumor-protecting effects of epithelial nicotinic acetylcholine receptors. Int. Immunopharmacol. 2015, 29, 36-44. [CrossRef]

110. Zacharias, W.J.; Frank, D.B.; Zepp, J.A.; Morley, M.P.; Alkhaleel, F.A.; Kong, J.; Zhou, S.; Cantu, E.; Morrisey, E.E. Regeneration of the lung alveolus by an evolutionarily conserved epithelial progenitor. Nature 2018, 555, 251-255. [CrossRef]

111. Hayflick, L. The Limited in Vitro Lifetime of Human Diploid Cell Strains. Exp. Cell Res. 1965, 37, 614-636. [CrossRef]

112. Gordon, D.E.; Jang, G.M.; Bouhaddou, M.; Xu, J.; Obernier, K.; White, K.M.; O’Meara, M.J.; Rezelj, V.V.; Guo, J.Z.; Swaney, D.L.; et al. A SARS-CoV-2 protein interaction map reveals targets for drug repurposing. Nature 2020, 583, 459-468. [CrossRef]

113. Walls, A.C.; Park, Y.J.; Tortorici, M.A.; Wall, A.; McGuire, A.T.; Veesler, D. Structure, Function, and Antigenicity of the SARS-CoV-2 Spike Glycoprotein. Cell 2020, 181, 281-292.e6. [CrossRef]

114. Kagan, J.C. Signaling organelles of the innate immune system. Cell 2012, 151, 1168-1178. [CrossRef]

115. Novoa, R.R.; Calderita, G.; Arranz, R.; Fontana, J.; Granzow, H.; Risco, C. Virus factories: Associations of cell organelles for viral replication and morphogenesis. Biol. Cell 2005, 97, 147-172. [CrossRef] [PubMed]

116. Munger, J.; Bajad, S.U.; Coller, H.A.; Shenk, T.; Rabinowitz, J.D. Dynamics of the cellular metabolome during human cytomegalovirus infection. PLoS Pathog. 2006, 2, e132. [CrossRef] [PubMed]

117. Duarte, S.; Viedma-Poyatos, A.; Navarro-Carrasco, E.; Martinez, A.E.; Pajares, M.A.; Perez-Sala, D. Vimentin filaments interact with the actin cortex in mitosis allowing normal cell division. Nat. Commun. 2019, 10, 4200. [CrossRef] [PubMed]

118. Cheng, F.; Eriksson, J.E. Intermediate Filaments and the Regulation of Cell Motility during Regeneration and Wound Healing. Cold Spring Harb. Perspect. Biol. 2017, 9. [CrossRef]

119. Gan, Z.; Ding, L.; Burckhardt, C.J.; Lowery, J.; Zaritsky, A.; Sitterley, K.; Mota, A.; Costigliola, N.; Starker, C.G.; Voytas, D.F.; et al. Vimentin Intermediate Filaments Template Microtubule Networks to Enhance Persistence in Cell Polarity and Directed Migration. Cell Syst. 2016, 3, 252-263. [CrossRef]

120. Snyder, L.D.; Mosher, C.; Holtze, C.H.; Lancaster, L.H.; Flaherty, K.R.; Noth, I.; Neely, M.L.; Hellkamp, A.S.; Bender, S.; Conoscenti, C.S.; et al. Time to diagnosis of idiopathic pulmonary fibrosis in the IPF-PRO Registry. BMJ Open Respir. Res. 2020, 7 , e000567. [CrossRef]

121. Ramos, I.; Stamatakis, K.; Oeste, C.L.; Perez-Sala, D. Vimentin as a Multifaceted Player and Potential Therapeutic Target in Viral Infections. Int. J. Mol. Sci. 2020, 21, 4675. [CrossRef]

122. Lu, R.; Zhao, X.; Li, J.; Niu, P.; Yang, B.; Wu, H.; Wang, W.; Song, H.; Huang, B.; Zhu, N.; et al. Genomic characterisation and epidemiology of 2019 novel coronavirus: Implications for virus origins and receptor binding. Lancet 2020, 395, 565-574. [CrossRef]

123. Cruz, G.N.F.; Christoff, A.P.; de Oliveira, L.F.V. Equivolumetric protocol generates library sizes proportional to total microbial load in nextgeneration sequencing. BioRxiv 2020. [CrossRef]

124. Webb, B.J.; Peltan, I.D.; Jensen, P.; Hoda, D.; Hunter, B.; Silver, A.; Starr, N.; Buckel, W.; Grisel, N.; Hummel, E.; et al. Clinical criteria for COVID-19-associated hyperinflammatory syndrome: A cohort study. Lancet Rheumatol. 2020, 2, e754-e763. [CrossRef] 
125. Polidoro, R.B.; Hagan, R.S.; de Santis Santiago, R.; Schmidt, N.W. Overview: Systemic Inflammatory Response Derived from Lung Injury Caused by SARS-CoV-2 Infection Explains Severe Outcomes in COVID-19. Front. Immunol. 2020, $11,1626$. [CrossRef] [PubMed]

126. Cimpean, A.M.; Raica, M. Historical Overview of In Vivo and In Vitro Angiogenesis Assays. Methods Mol. Biol. 2021, 2206, 1-13. [PubMed]

127. De Spiegelaere, W.; Casteleyn, C.; Van den Broeck, W.; Plendl, J.; Bahramsoltani, M.; Simoens, P.; Djonov, V.; Cornillie, P. Intussusceptive angiogenesis: A biologically relevant form of angiogenesis. J. Vasc. Res. 2012, 49, 390-404. [CrossRef] [PubMed]

128. Bychkov, M.; Shenkarev, Z.; Shulepko, M.; Shlepova, O.; Kirpichnikov, M.; Lyukmanova, E. Water-soluble variant of human Lynx1 induces cell cycle arrest and apoptosis in lung cancer cells via modulation of alpha7 nicotinic acetylcholine receptors. PLoS ONE 2019, 14, e0217339. [CrossRef]

129. Shulepko, M.A.; Bychkov, M.L.; Shlepova, O.V.; Shenkarev, Z.O.; Kirpichnikov, M.P.; Lyukmanova, E.N. Human secreted protein SLURP-1 abolishes nicotine-induced proliferation, PTEN down-regulation and alpha7-nAChR expression up-regulation in lung cancer cells. Int. Immunopharmacol. 2020, 82, 106303. [CrossRef] [PubMed]

130. Matsuyama, T.; Kubli, S.P.; Yoshinaga, S.K.; Pfeffer, K.; Mak, T.W. An aberrant STAT pathway is central to COVID-19. Cell Death Differ. 2020. [CrossRef] [PubMed]

131. Dhillon, P.; Breuer, M.; Hirst, N. COVID-19 breakthroughs: Separating fact from fiction. FEBS J. 2020. [CrossRef]

132. Farsalinos, K.; Niaura, R.; Le Houezec, J.; Barbouni, A.; Tsatsakis, A.; Kouretas, D.; Vantarakis, A.; Poulas, K. Editorial: Nicotine and SARS-CoV-2: COVID-19 may be a disease of the nicotinic cholinergic system. Toxicol. Rep. 2020, 7, 658-663. [CrossRef] 